\title{
Are BET Inhibitors yet Promising Latency-Reversing Agents for HIV-1 Reactivation in AIDS Therapy?
}

\author{
Thanarat Salahong ${ }^{1}\left(\mathbb{D}\right.$, Christian Schwartz ${ }^{2, *}$ and Rungroch Sungthong $3,4, *$ (D) \\ 1 Department of Immunology, Faculty of Medicine Siriraj Hospital, Mahidol University, \\ Bangkok 10700, Thailand; thanarat.sal@student.mahidol.ac.th \\ 2 Research Unit 7292, DHPI, IUT Louis Pasteur, University of Strasbourg, 67300 Schiltigheim, France \\ 3 Institute of Biodiversity, Animal Health and Comparative Medicine, College of Medical Veterinary and Life \\ Sciences, University of Glasgow, Glasgow G61 1QH, UK \\ 4 Laboratory of Hydrology and Geochemistry of Strasbourg, University of Strasbourg, UMR 7517 CNRS/EOST, \\ 67084 Strasbourg CEDEX, France \\ * Correspondence: schwartz.christian@unistra.fr (C.S.); sungthong@unistra.fr (R.S.)
}

Citation: Salahong, T.; Schwartz, C.; Sungthong, R. Are BET Inhibitors yet Promising Latency-Reversing Agents for HIV-1 Reactivation in AIDS Therapy? Viruses 2021, 13, 1026. https://doi.org/10.3390/v13061026

Academic Editor: Italo Tempera

Received: 29 March 2021

Accepted: 26 May 2021

Published: 29 May 2021

Publisher's Note: MDPI stays neutral with regard to jurisdictional claims in published maps and institutional affiliations.

Copyright: (c) 2021 by the authors. Licensee MDPI, Basel, Switzerland. This article is an open access article distributed under the terms and conditions of the Creative Commons Attribution (CC BY) license (https:// creativecommons.org/licenses/by/ $4.0 /)$.

\begin{abstract}
AIDS first emerged decades ago; however, its cure, i.e., eliminating all virus sources, is still unachievable. A critical burden of AIDS therapy is the evasive nature of HIV-1 in face of host immune responses, the so-called "latency." Recently, a promising approach, the "Shock and Kill" strategy, was proposed to eliminate latently HIV-1-infected cell reservoirs. The "Shock and Kill" concept involves two crucial steps: HIV-1 reactivation from its latency stage using a latency-reversing agent (LRA) followed by host immune responses to destroy HIV-1-infected cells in combination with reinforced antiretroviral therapy to kill the progeny virus. Hence, a key challenge is to search for optimal LRAs. Looking at epigenetics of HIV-1 infection, researchers proved that some bromodomains and extra-terminal motif protein inhibitors (BETis) are able to reactivate HIV-1 from latency. However, to date, only a few BETis have shown HIV-1-reactivating functions, and none of them have yet been approved for clinical trial. In this review, we aim to demonstrate the epigenetic roles of BETis in HIV-1 infection and HIV-1-related immune responses. Possible future applications of BETis and their HIV-1-reactivating properties are summarized and discussed.
\end{abstract}

Keywords: HIV-1; latently HIV-1-infected cell; latency-reversing agent; BET protein; BRD2; BRD4; LRA; BETi; epigenetics; immune response

\section{Introduction}

Although antiretroviral therapy in AIDS patients reduces viremia, continuous administration of drugs is required, since HIV-1 gene transcription still occurs at a residual level in latently HIV-1-infected cell reservoirs, mainly in resting $\mathrm{CD}^{+} \mathrm{T}$ cells, in patients under combination antiretroviral therapy (cART) [1]. This residual transcription is associated with chronic immune activation and low-level inflammation, which support non-AIDS co-morbidities [2]. However, there is now compelling evidence that the composition of HIV-1 reservoir is heterogeneous [3]. Indeed, HIV-1 is latently established in various cell types such as hematopoietic stem cells, dendritic cells, microglial cells or in cells from the monocyte-macrophage lineage reviewed in [4-6]. Moreover, these cells localize in a variety of anatomical sites including tissues such as the blood, the brain, the gut-associated lymphoid tissue, the adipose tissue, the bone marrow, and the genital tract [7], making it difficult to clear all virus reservoirs.

A prerequisite to successfully eliminate reservoirs is to understand the molecular mechanisms implicated in the establishment and maintenance of HIV-1 latency. Understanding these mechanisms could help us to discover new target proteins in the viral cycle, which are not affected by cART [8]. Some of these molecular mechanisms have been identified. An important role for the cellular cofactor CTIP2 (Bcl11b) was shown 
in the establishment and the maintenance of HIV-1 post-integration latency in microglial cells [9-11]. CTIP2 works as a scaffold protein recruiting at least two different complexes in microglial cells. As part of a chromatin remodeling complex, CTIP2 is associated with the lysine demethylase LSD1, the histone deacetylases HDAC1 and HDAC2, and the histone methyltransferase SUV39H1 [9,12-14]. Moreover, CTIP2 is also involved in the control of the elongation process of gene transcription by inhibiting P-TEFb functions $[15,16]$.

To date, two strategies are considered to achieve a functional and/or a sterilizing cure: the "Shock and Kill" and the "Block and Lock" strategies (Figure 1). The "Block and Lock" strategy aims to reach long-term control of HIV-1 in the absence of cART by inducing long lasting inhibition of HIV-1 gene expression [17]. Latency-promoting agents (LPAs) are molecules inhibiting HIV-1 expression, thus inducing deep latency (the "Block") and preventing HIV-1 gene transcription (the "Lock") [18]. The LPA, didehydro-cortistatin A (dCA), an inhibitor of the transactivator Tat, showed promising effect in preliminary results. However, a recent in vitro study described virus resistance to this factor [19]. Another recent pilot study, which assessed the effects of metformin on mTOR activation, showed reduced residual HIV-1 gene transcription in the gut-reservoir [20], suggesting that it could be a pertinent candidate among LPAs used in the "Block and Lock" strategy [21].

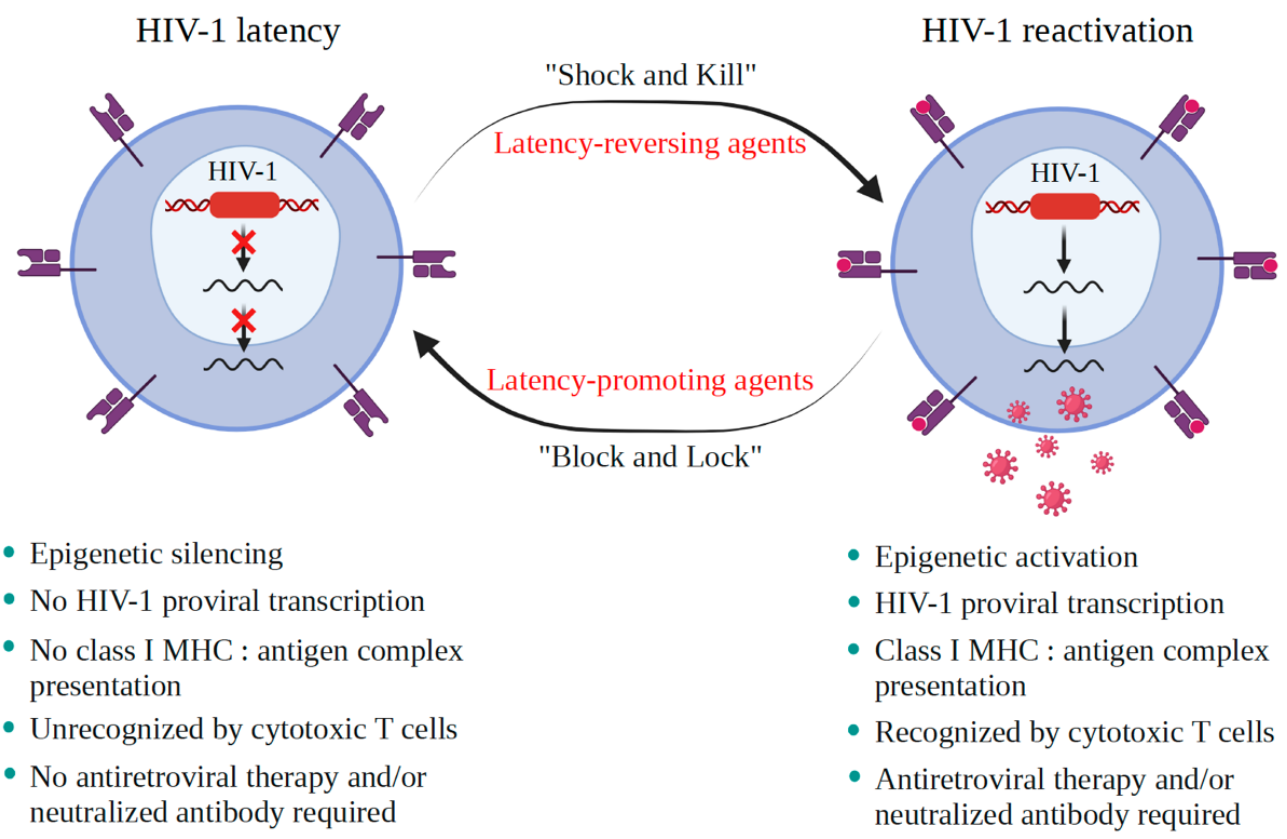

Figure 1. Concepts of "Shock and Kill" and "Block and Lock" strategies in AIDS therapy. Latencyreversing agents induce HIV-1 transcription via epigenetic activations in the "Shock" step. Then, these viral particles will be processed and released, leading to the elimination of the infected cells by immune clearance and to the elimination of the virus by combination antiretroviral therapy in the "Kill" step. Immune clearance involves CD8 ${ }^{+}$cytotoxic T cells (CLTs) that recognize the MHC I: HIV-1 peptide complex on the surface of HIV-1-infected cells and induce apoptosis by secreting granzyme B and perforin. An optimization of immunotherapy by using therapeutic vaccines to enhance CTL responses, broadly neutralizing antibodies and/or immune modulators are needed since viral reservoirs do not die from viral cytopathic effects or via the cytotoxic CTL responses. In the "Block and Lock" strategy, latency-promoting agents are applied for blocking the HIV-1 transcription in the "Block" step, and epigenetic silencing occurs in the "Lock" step. The figure was created with BioRender.com.

The "Shock and Kill" strategy proceeds by first reactivating the latent virus and subsequently eliminating it by a reinforced cART. Clearance of the reservoirs is achieved either by the cytopathic effect of the treatment on the reactivated virus and/or by inducing the immune system via the actions of cytotoxic T cells (CTLs) [22]. For the time being, the 
"Shock and Kill" strategy is only conceivable with circulating reservoirs such as the resting $\mathrm{T} \mathrm{CD}^{+}$cells. Indeed, the "Shock and Kill" strategy cannot be applied when targeting brain reservoirs due to several unique characteristics of the central nervous system discussed in [10].

\section{State of the Art of the "Shock" Step}

The "Shock" step requires latency-reversing agents (LRAs), which play a crucial role in the reactivation of the virus as viral transcription activators. There are two main classes of drugs of LRAs under investigations.

The first class includes HDAC inhibitors (HDACis) such as valproic acid, vorinostat, panobinostat, romidepsin, and suberoylanilide hydroxamic acid (SAHA). For instance, SAHA activates viral transcription by inhibiting HDAC activity, which otherwise represses transcription $[23,24]$. In the first class, we find the histone methyl transferase inhibitors (HMTis) such as chaetocin and BIX 01294 and DNA methylation inhibitors such as 5-AzadC as well, as they are also involved in the epigenetic control of HIV-1. HDACis and HMTis have been revealed to reactivate to some extent HIV-1 expression both in vitro [25-28] and ex vivo [29]. However, among LRAs only HDACis (i.e., SAHA, panobinostat, romidepsin, and valproic acid) have been assessed in clinical trials [24]. Unfortunately, these compounds caused severe side effects such as anorexia, atrial fibrillation, diarrhea, exhaustion, and thrombocytopenia in AIDS patients [30].

The second class of LRAs comprises five subclasses of molecules: (i) non-histone chromatin modulators such as triazolothienodiazepine (JQ1) and BAF inhibitors; (ii) stimulators of positive cellular factors (NF-kB and the coactivator of NF-kB and P-TEFb) [31]. These drugs prompt the expression of positive cellular factors and/or their release from the inactive complex [32,33]. For example, prostratin, bryostatin, or ingenol B activates the PKC pathway and in consequence NF-kB and P-TEFb are released from the inactive complexes. Besides these actions, these agents also increase P-TEFb expression [34-36]. The active positive cellular factors in turn enable HIV-1 reactivation [37]; (iii) Toll-like receptor agonists; (iv) extracellular stimulators such as TNF $\alpha$ and PHA; v) miscellaneous drugs that comprise uncommon drugs such as disulfiram reviewed in [38].

However, these drugs used alone are ineffective to completely reactivate HIV-1 expression ex vivo $[39,40]$. This suggests that multifactorial mechanisms involving molecular reactions with underlying stochastic nature are responsible for the development of latency [3]. Thus, it appears that the feasibility of this strategy is rather difficult, mainly because of the poor comprehension of the molecular mechanisms involved in the establishment and maintenance of HIV-1 latency in reservoirs [41].

In latently HIV-1-infected cells, virus production is essentially blocked on the level of HIV-1 transcription. It is known that HIV-1 transcription is under epigenetic control of the HIV-1 promoter. Reactivation of transcription is inhibited directly by specific inhibitory mechanisms and/or by the sequestration of positive TFs. For instance, besides CTIP2 and LSD1, three new factors, Hic-1, HMGA1, and KAP1, have been involved in the repression of HIV-1 transcription in microglial cells [10,16,42]. These studies highlight the complexity of the molecular mechanisms underlying HIV-1 latency and explain why single LRAs failed in initial clinical trials. Post transcriptional events such as mRNA export, splicing and translation might also be essential in latency and deserve far more consideration $[43,44]$.

To override these limitations, it was suggested that combination of drugs might improve the efficiency of reactivation along with reduced toxicity because of the synergetic effect and lower doses of drugs. Several clinical trials using the combinatorial approach are underway (reviewed in [38]). Next-generation LRAs are also in the focus of research. For instance, the inhibitors of bromodomains and extra-terminal domain (BET) family proteins, which are the master transcription elongation factors in epigenetic modification, are in the center of many current studies. BET inhibitors (BETis), such as JQ1 [45] and benzotriazolodiazepine (I-BET762) [46], initially were tested for their anticancer and antiinflammatory effects, respectively. Research has been extended to evaluate the epigenetic 
roles and therapeutic potentials of BETis in other diseases (e.g., neurological disorders and obesity) [47], including AIDS [48,49]. A set of pioneer studies proved that JQ1 was a potential LRA candidate demonstrating strong reactivation of HIV-1 expression [48,49]. To date, there are growing numbers of synthesized BETis. However, their roles in epigenetics, HIV-1 reactivation, and host immune responses, together with their clinical perspectives in AIDS therapy, still need further investigation.

\section{Roles of BET Family Proteins and Their Inhibitors in HIV-1-Infected Cells}

Epigenetic modifications involve histones, chromatin-associated proteins, and the DNA. Proteins mediating these dynamic processes are the so-called "readers", "writers", and "erasers" [50,51]. Post-translational modifications of histones such as acetylation, methylation, sumoylation, phosphorylation, and ubiquitinylation, determine the compaction of chromatin and its permissiveness of transcription. Nuc-1, a nucleosome located immediately downstream of the HIV-1 transcriptional initiation site, is known to directly impede the HIV-1 promoter (the long-terminal repeat (LTR)) activity. Epigenetic modification and disruption of Nuc-1 was shown to be a prerequisite of activation of LTR-driven transcription and viral expression $[52,53]$. Deacetylases (erasers) are recruited by several transcription factors (TFs), including the homodimer p50, YY1, LSF or thyroid hormone receptors [53]. It was found that recruitment of erasers such as deacetylases and methylases on the LTR was linked to epigenetic modifications (deacetylation of H3K9 followed by H3K9 trimethylation and recruitment of $\mathrm{HP} 1$ proteins) in $\mathrm{CD}^{+} \mathrm{T}$ cells [54]. It was suggested that when the positive histone charge is neutralized by acetylation induced by the histone acetylase transferase (a writer), the chromatin structure is relaxed, and recognized by BET family proteins. These proteins have two tandem bromodomains (BRDs: BD1 and BD2) and one extra-terminal (ET) domain [55-57]. All BRDs have conserved sequences of $\sim 110$ amino acids, structurally consisting of four alpha-helices $(\alpha Z, \alpha A, \alpha B$, and $\alpha C)$ and two loops (ZA and BC). The ET domain is a conserved region of $\sim 80$ amino acids. BET family proteins bind to the acetylated histone on their BRDs, allowing the ET domain to recruit TFs to form a transcription complex. Due to these functionalities, BET family proteins behave as epigenetic readers. The four members of BET family proteins are BRD2, BRD3, BRD4, and BRDT.

\subsection{BRD4}

The epigenetic reader protein BRD4 binds histones on acetylated sites. BRD4 as a scaffolding protein recruits many factors, e.g., $\mathrm{NFKB}$ and $\mathrm{P}-\mathrm{TEFb}$, which are involved in the regulation of gene expression [58,59]. Indeed, in addition to the conserved BRD and ET domain which characterize members of the BET family protein, BRD4 contains a third functional domain termed the P-TEFb-interacting domain (PID) [60]. BRD4 is described as a regulator of gene transcription elongation which occurs via its association with $\mathrm{P}-\mathrm{TEFb}$ to form the super elongation complex (SEC) [61]. BRD4 recruits P-TEFb on the PID domain and releases it in its active state from the 7SK inactive complex, which also contains the 7SK RNA, HEXIM1, and CTIP2 inhibitors (Figure 2). Such inactive ribonucleoprotein complex associated with P-TEFb has been described in HeLa cells and other tumor cell lines [62,63]. However, in the case of HIV-1 transcription, Tat is a much stronger activator of P-TEFb than BRD4. Tat induces productive expression of HIV-1, while HIV-1 gene elongation is aborted in case of BRD4 stimulation. It is thought that BRD4 competes with the transactivator Tat, thus limiting HIV-1 transcription (Figure 2). It was shown that the BET inhibitor JQ1 blocked the interaction of BRD4 with the elongation factor P-TEFb composed of cyclindependent kinase 9 (CDK9) and cyclin T1 (CycT1). The results suggested that P-TEFb was free to associate with Tat, initiating productive HIV-1 elongation [64]. Once docked on the HIV-1 promoter, BRD4 induces autophosphorylation of CDK9 at threonine 29 inactivating CDK9 $[59,65]$. Another study [66] assumed that BRD4 interacted directly with the virulence factor Vif (viral infectivity factor) and CDK9 to form a ribonucleoprotein complex [67]. 
This interaction might allow cells to rest in the $G_{2}$ phase, which supposes to enhance the establishment of HIV-1 latency.

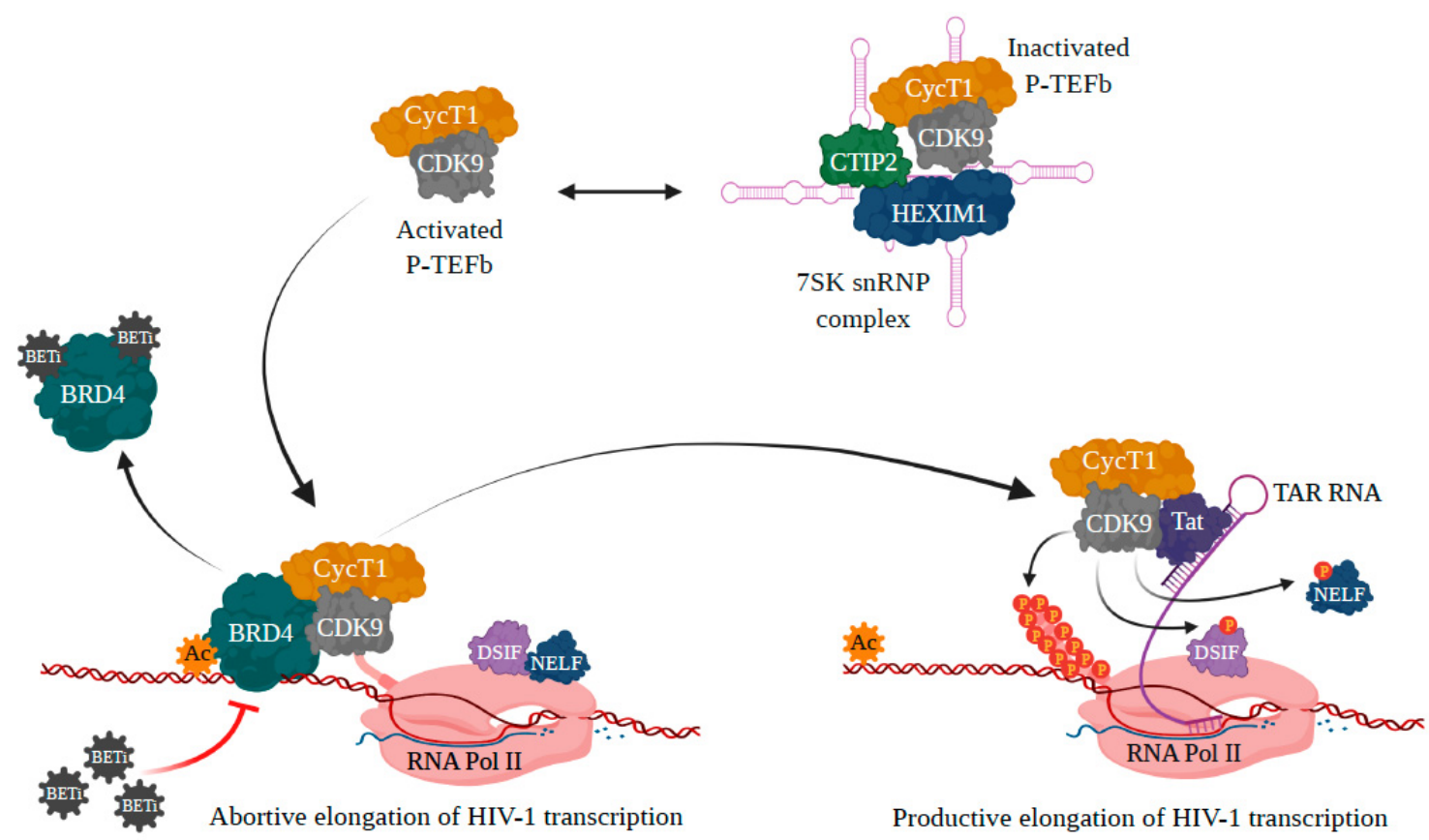

Figure 2. Roles of BET proteins and BETis in HIV-1 latency through the Tat-dependent manner. The 7SK snRNP forming complex which contains HEXIM1 and CTIP2 inactivates P-TEFb (CDK9 and CylinT1). During the cell activation, P-TEFb is released from the complex and becomes an active form that is the target for the viral Tat protein and BRD4. In HIV-1 latency, BRD4 competes with the viral Tat protein for recruiting active P-TEFb, leading to the low productive HIV-1 transcription. Thus, BRD4 inhibition by BETis increases the viral transcription via the phosphorylation of negative elongation factors (DSIF and NELF) and the serine 2 in CTD of RNA Pol II by the viral Tat/P-TEFb complex. The figure was created with BioRender.com.

Of note, the activity of JQ1 is essentially Tat-dependent but some studies reported that JQ1 induced activation of HIV-1 transcription in cell lines in the absence of Tat [68]. This might be explained by the existence of a short isoform of BET family member BRD4 (BRD4S), which acts as a corepressor of HIV-1 transcription. Indeed, the BRD4 isoform is bound to BRG1, a catalytic subunit of the BRG1-associated factors (BAF). BAF is a mammalian SWI/SNF chromatin-remodeling complex with known repressive functions in HIV-1 transcription [69].

Besides JQ1, other BETis are currently tested, such as OTX015, UMB-136, MMQO and I-BET151 [70]. Interestingly, OTX015 increases CDK9 occupancy at the HIV-1 promoter, which in turn phosphorylates RNA Pol II carboxy-terminal domain (CTD) [71], enabling productive elongation.

\section{2. $B R D 2$}

In 1992, Beck and colleagues were the first to reveal the importance of BRD2 (formerly, a Really Interesting New Gene 3, RING3) in human developmental regulation mechanisms [72]. BRD2 is a major player in epigenetics. Along with BRD4, BRD2 belongs to the BET family but lacks a C-terminal PID domain. However, BRD2 was found to coimmunoprecipitate with $\mathrm{P}-\mathrm{TEFb}$ [73]. A crucial role of BRD2 bound to acetylated histones is to activate $\mathrm{P}-\mathrm{TEFb}$ (Figure 3a) [60]. Interestingly, BRD2 was found to function as a repressor of HIV-1 in latent cells. Indeed, depletion of BRD2 by shRNA activated HIV-1 transcription. In latently HIV-1-infected cells, the level of reactivation following knockdown of BRD2 was comparable to that of the BETi JQ1. In this case, reactivation of HIV-1 was dependent on $\mathrm{P}-\mathrm{TEFb}$ activity but independent of the viral Tat [68]. It is believed that the mechanism of 
action involves co-repressor complexes including HDACs since BRD2 bound on an HDAC complex was observed [74]. In addition, BRD2 was shown to interact with the E2F1 TF. It was also shown that E2F1 was associated to the repressor NF-kB p50 on the HIV-1 promotor and blocked NF-kB p50/p65 dependent HIV-1 transcription [75]. In view of these results, it was postulated that BRD2 is recruited on the HIV-1 LTR by E2F1/p50 heterodimers while also enrolling repressor complexes which contain the erasers HDACs [76]. However, it is possible that another mechanism of action underlies repression of HIV-1 transcription by BRD2. It was shown that BRD2 associated with the architectural/insulator protein CCCTCbinding factor (CTCF), and they formed a transcriptional boundary [77]. Interestingly, CTCF was found associated to the HIV-1 promoter and prevented the formation of the NF$\mathrm{kB} /$ LTR complex (Figure 3b) [78]. Bearing in mind the intricate epigenetic roles of BRD2, BETis may either hamper BRD2 recruiting the repressor complex (Figure 3a) or weaken the transcriptional boundary formation (Figure $3 b$ ). In both cases, virus transcription and reactivation should take place.
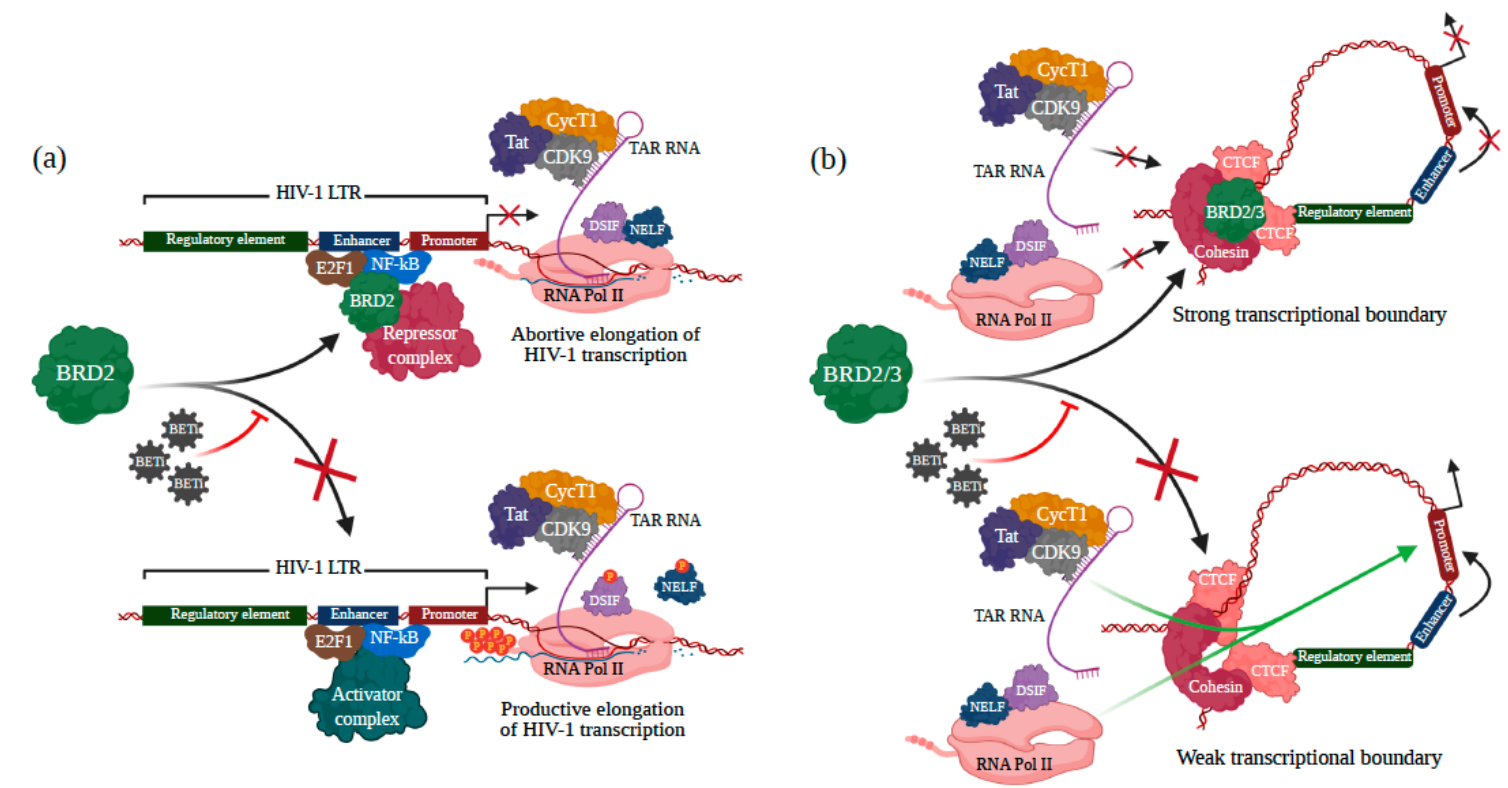

Figure 3. Roles of BET proteins and BETis in HIV-1 latency through the Tat-independent manner. (a) NF- $\mathrm{KB}$ and E2F1 initially recruit BRD2 to the viral LTR site (which consists of a regulatory element, an enhancer, and a promoter), and BRD2 recruits further the repressor complex by recognizing the acetylated lysine residue on such complex. The formation of the repressor complex represses HIV-1 transcription. When BETis inhibit BRD2, the activator complex binds to the viral LTR site, leading to the activation of viral transcription. (b) CTCF recruits BRD2 or BRD3 (BED2/3) to interact with the CTCF-cohesin complex and forms a transcriptional boundary that interrupts the viral transcription. BRD2/3 induces a strong transcriptional boundary that may modify the chromatin structure and interfere with the accessibility of HIV-1 transcription components. Hence, BRD2/3 inhibited by BETis weakens the transcriptional boundary and enhance the HIV-1 transcription by causing relaxed chromatin structure and facilitating the accessibility of transcription components to the viral genome site. The figure was created with BioRender.com.

\subsection{Other BET Family Proteins}

It is not clear whether other BET family proteins such as BRD3 and BRDT are involved in the epigenetic regulation of HIV-1.

As described for BRD2 and BRD4, BRD3 is recruited onto the HIV-1 promotor via acetylated histones and permits the recruitment of TFs. BRD3 also provides support for interactions of epigenetic regulators to facilitate RNA Pol II performance $[79,80]$. The proteinprotein interactions of BRD3 with other TFs/coactivators often regulate and activate the innate immune response [81]. For instance, a recent study revealed that BRD3 fostered the interferon regulatory factor IRF3 / p300 complex recruitment to the Ifnb1 promoter [82]. Like BRD2, BRD3 interacts with CTCF to form a transcriptional boundary $[77,83]$. Based 
on recent reports $[77,83]$, we suppose that BRD3 induced HIV-1 latency, or its inhibitors induced reactivation, occurring via the transcriptional boundary-forming platform. However, the specific role of BRD3 in HIV-1 infection is still to be established.

With its definition "bromodomains specific-testis factor, BRDT" is typically silent in somatic and germ-line cells but has a crucial role in spermatogenesis and oogenesis at the onset of meiotic cell differentiation [84,85]. Moreover, in a study of a mouse model, it was unveiled that knockdown of the Brdt gene induces apoptosis during meiosis [84]. Although BRDT can interact with P-TEFb like BRD2 and BRD4, its uniquely affiliated cells are not the targets for HIV-1 infection.

\section{BETis and Immunity}

Although the epigenetic roles of BETis in HIV-1 latency and reactivation have been demonstrated and therefore are promising tools in the "Shock and Kill" strategy, further studies are needed to evaluate the consequences of their effects on the host immune responses. Here, we discuss how BETis affect the host immune system response to HIV-1 infection.

\subsection{Innate Immunity}

Innate immunity is the first-line host defensive system to tackle pathogenic invasion. It involves diverse innate immune cells (e.g., dendritic cells, macrophages, NK cells), specific organs, and chemical molecules. The immune cells' own pattern recognition receptors behave as host sensors for any invasive pathogens and host cell components released during cell damage and death [86-88]. Downstream signaling of the receptors is the keystone to prompt immune responses. BET proteins and especially BRD4 trigger the innate immunity through numerous downstream signaling pathways, such as Janus kinase-signal transducer and activator of transcription protein (JAK-STAT), NF-kB, or nucleotide-binding oligomerization domain-like receptor (NLR). Activation of these pathways promotes inflammation and pyroptosis (Figure 4a) [89]. During acute HIV-1 infection, diverse inflammatory cytokines are increasingly produced by innate immune cells, causing the cytokine storm, which is responsible for the high mortality rate in AIDS patients. At the same time, interleukin 6 (IL-6) and tumor necrosis factor-alpha (TNF- $\alpha$ ) increase and are linked to the development of cardiovascular disease, atherosclerosis, and others [90-93]. Although antiretroviral therapy minimizes inflammation in AIDS patients, it is still higher than that of healthy ones [91,94-98]. Therefore, suppression of excessive cytokine production may improve AIDS therapy and patient immune responses. BETis have been proved for their capabilities to reduce IL-6, interferon gamma-induced protein 10 (IP-10), macrophage inflammatory protein 1 (MIP-1), and TNF- $\alpha$ and to prevent hyperinflammatory conditions during HIV-1 infection [99-102]. The inhibitors also suppress dendritic cell maturation, leading to the diminution of cytokine production $[103,104]$. Even though these benefits assure an important role for BETis in HIV-1 infection prompted hyperinflammation regulation, their long-term effects on the immune response need to be investigated in the future.

\subsection{Adaptive Immunity}

Another host defensive mechanism against invasive pathogens is adaptive immunity, and its key players are $\mathrm{CD} 4^{+} \mathrm{T}$ helper cells. $\mathrm{CD}^{+} \mathrm{T}$ helper cells are categorized based on the differences of cytokine production and surface marker expression $[105,106]$. T helper 1 (Th1) cells destroy intracellular pathogens by releasing interferon-gamma, IFN- $\gamma$ being the signature cytokine. IFN- $\gamma$ stimulates the adaptive and the innate immune systems, such as B cells, CTLs, classical macrophages, and NK cells. A recent study reported that a BETi (JQ1) suppressed IFN- $\gamma$ expression in Th1 cells and memory CD4 ${ }^{+}$T cells [107]. Although IFN- $\gamma$ is not a potent antiviral cytokine, circulating IFN- $\gamma$ level is upregulated in AIDS patients [108,109]. It is still interesting how suppression of this cytokine affects immune responses during HIV-1 infection. Another subpopulation of $\mathrm{CD}^{+}{ }^{+} \mathrm{T}$ helper cells 
is T helper 2 (Th2) cells that produce IL-4, IL-5, and IL-13 as defining cytokines [105,110]. Th2 cells can eradicate helminth infection through eosinophil stimulation, immunoglobulin E secretion, and mast cell activation. Additionally, Th2 cells are involved in tissue repair by promoting the alternatively activated macrophage (M2) polarization. A recent study [111] revealed that an elevated level of the chemokine (C-C motif) chemokine ligand 18 (an M2 macrophage marker) corresponded to a low number of $\mathrm{CD} 4^{+} \mathrm{T}$ cells in AIDS patients with antiretroviral therapy. Thus, immune responses of Th2 cells during HIV-1 infection are appealing to explore further.

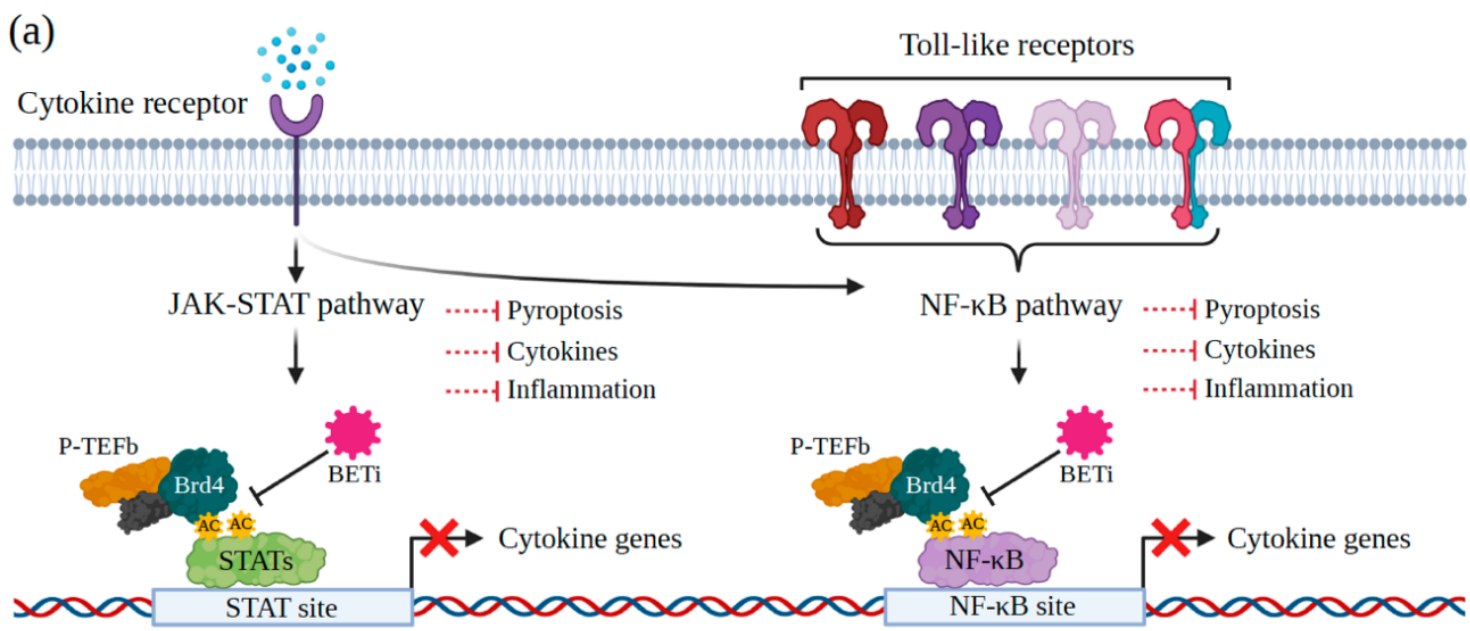

(b)

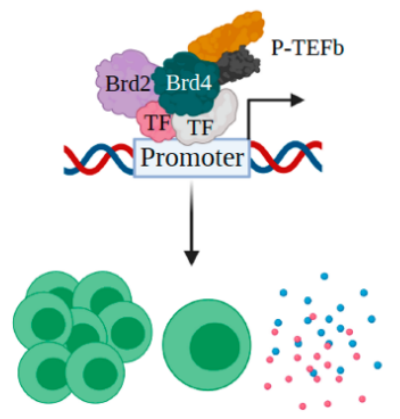

Th17 cell diffentiation/proliferation

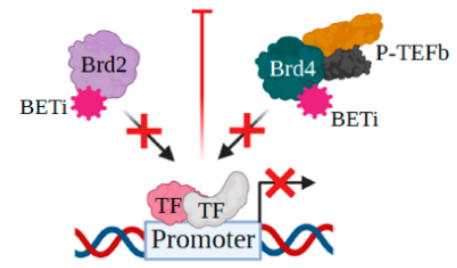

(c)

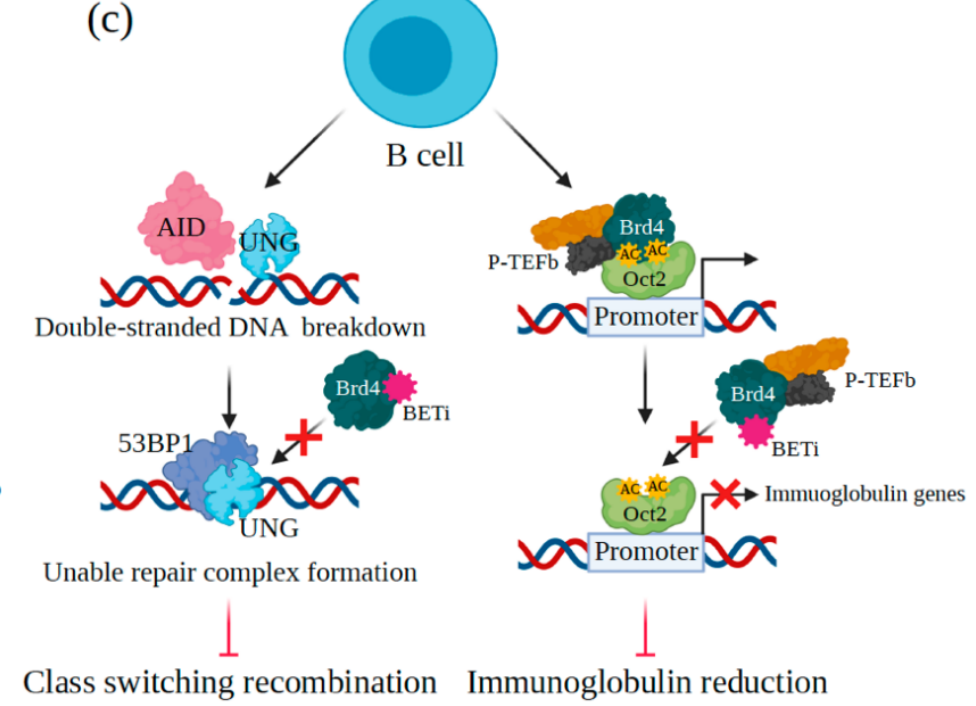

Figure 4. BETis and immune responses. (a) BRD4 recognizes an acetyl group on STATs and NF-kB, which are critical transcription factors in JAK-STAT and NF-KB signaling pathways, respectively. Once immune cells are exposed to BETis, BRD4 is then blocked, resulting in the decreased expression of cytokine gene. (b) BETis directly inhibit the functions of BRD2 and BRD4 mediating Th17 cell differentiation and proliferation in transcription regulation. (c) When BETis block BRD4, the repair complex is not formed, leading to the undeveloped CSR in B cells. Besides, after inhibiting BRD4, immunoglobulin genes are significantly suppressed, causing a low antibody level (AID is an activation-induced deaminase). The figure was created with BioRender.com.

In addition to Th1 and Th2 cells, T helper 17 (Th17) cells producing dominant cytokines (IL-17 and IL-22) can defeat invasive extracellular microbes at mucosal sites. However, Th17 cells are main targets of HIV-1 and make viral reservoir to persist, which leads to chronic inflammation $[112,113]$. These $T$ helper cells highly express $C-C$ chemokine receptor type 5 (CCR5) and minor receptors (C-C chemokine receptor type 6 (CCR6) and CXC 
chemokine receptor (CXCR) type 6). They facilitate infection by HIV-1 disrupting mucosal Th17 cell function and mucosal immune homeostasis. Antiretroviral therapy in AIDS patients cannot repair Th17 cell function [114]. One explanation is that increased indoleamine 2,3-dioxygenase 1 (IDO1) activity further induces regulatory T cell (Treg) expansion (i.e., inhibiting Th17 cell differentiation) by catabolizing tryptophan to kynurenine. Lately, the IDO1 promoter is identified as a binding site for all BET family proteins (BRD2, BRD3, and BRD4) and the RNA Pol II [115]. Although some BETis (i.e., ABBV-075, JQ1, and OTX015) efficiently reduce the expression of both constitutive and IFN- $\gamma$-induced IDO1 and kynurenine formation [115], their functions in mucosal Th17 cell repair are still unknown. Many studies proved that BETis could suppress Th17 cell differentiation/proliferation, cytokine production, and surface markers (Figure $4 b$ ) [116-118]. Therefore, Th17 cell recovery would be another preferable characteristic of potential LRAs for future AIDS therapy.

Treg cells, also known as "suppressor T cells", are among the HIV-1 infected cells and responsible for the persistence of HIV-1 reservoirs [119]. Treg cells inhibit cell maturation of CTLs and in consequence presentation of B7-CD28 antigen. Moreover, Treg cells produce anti-inflammatory cytokines (i.e., IL-2, IL-10, and TGF- $\beta$ ) that further suppress other immune cells. Some studies found that Forkhead box-P3 (FOXP3, a master TF for regulating differentiation and suppressive functions of Treg cells) expression increased in AIDS patients and repressed HIV-1 transcription [120,121]. Previous studies [120,122] discovered that DNA methylation was altered during HIV-1 infection. Demethylation of the FOXP3 promoter was significantly higher in AIDS patients than in healthy ones, which led to the high FOXP3 expression and increased number of Treg cells in the gut mucosa. This observation suggests that HIV-1 may direct the replication of Treg cells by altering the FOXP3 methylation pattern. Although a BETi (JQ1) is proved to attenuate $\mathrm{CD} 4^{+} \mathrm{FOXP} 3^{+}$ Treg cell suppressive function in lung cancer therapy [123], how BET family proteins associate with FOXP3-promoting Treg cell functions is still unknown.

CTLs (or $\mathrm{CD}^{+} \mathrm{T}$ cells) eliminate HIV-1-infected cells after recognizing viral peptides presented on their major histocompatibility complex class I [124,125]. Studies suggested that BRD4 inhibited by BETis is related to the decreased CTL differentiation and proliferation [126-128]. However, the precise mode of interactions between BET family proteins and CTLs needs further elucidation. During chronic HIV-1 infection, CTL exhaustion is developed (i.e., reduced proliferation, decreased IFN- $\gamma$ production, and insufficient cytotoxic activity), leading to defect HIV-1 clearance $[129,130]$. The programmed cell death protein 1 (PD-1) is a master inhibitory immune checkpoint molecule that interacts with the programmed death-ligand 1 (PD-L1) in CTL exhaustion development. Some BETis can interrupt the PD-1/PD-L1 signaling pathway in cancer treatments [131,132]. It would be interesting to examine how BETis affect CTL exhaustion during chronic HIV-1 infection. B cells are another key player in HIV-1 infection, that produce specific antibodies inactivating viral particles during the reinfection cycle [133-135]. B cell functions are also affected by BETis as BRD4 is one of the regulators in class switch recombination (CSR), a unique mechanism for altering specific B cells (Figure 4c) [136,137]. Inhibition of BRD4 leads to the reduced accumulation of 53BP1 (a p53-binding protein required in DNA repair) and uracil DNA glycosylase (UNG, generating DNA double-strand breaks) in the CSR process (Figure 4c) [136-139]. Besides, BETis block the interaction between Brd4 and Oct2 (an immunoglobulin promoter-binding TF), decreasing immunoglobulin production and B cell proliferation rate (Figure 4c) [140].

Although BETis are engaged in innate and adaptive immune responses, little is known about their molecular immunological influence on CTL development and functions. Besides, the impact of BETis on immune responses during HIV-1 infection still needs to be assessed using appropriate models in particular in vivo. Filling these knowledge gaps may underpin the implementation of BETis in future AIDS therapy. 


\section{BETis: Current and Beyond}

Several BETis are investigated in clinical trials for their effectiveness in various diseases but not AIDS [141,142]. Although some studies unveiled HIV-1 latency-reversing activities of BETis, their implementations as LRAs in AIDS therapy are still far away. To our knowledge, I-BET-151 is the only BETi that was tested in vivo for its functions in HIV-1 reactivation [143]. Here, we describe some currently interesting BETis and their epigenetic roles relevant to HIV reactivation, impacts on host immune responses, and clinical perspectives (Table 1). We also address the limitations and discuss potential applications of BETis in AIDS therapy. 
Table 1. Currently interesting BETis and their potentials in AIDS therapy.

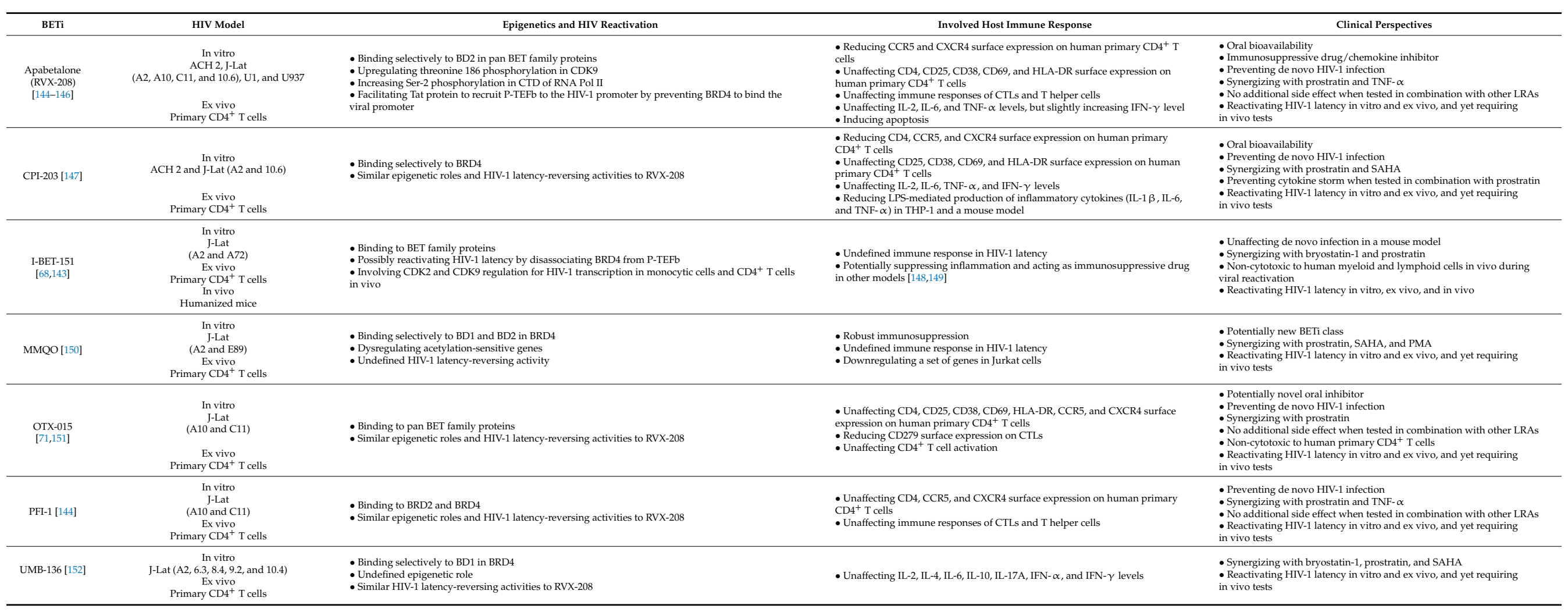


Apabetalone (RVX-208), CPI-203, I-BET-151, MMQO, OTX-015, PFI-1, and UMB-136 are interesting BETis that demonstrate similar HIV-1-reactivating mechanisms (Table 1). Some of these inhibitors were proved to inhibit BRD4, while some could block two or more BET family proteins (i.e., RVX-208, I-BET-151, OTX-015, and PFI-1) (Table 1). Studies of the BETis-BET family proteins interactions provide a comprehensive understanding of how viruses establish latency and how to process with optimal reactivation of the virus. Most BETis principally reactivate HIV-1 by inhibiting BRD4, which allows P-TEFb recruited by Tat on the viral promoter $[71,144,145,147,151]$. BETis also induce phosphorylation on threonine 186 of CDK9 and its subsequent activation and phosphorylation of serine 2 of the CTD of RNA Pol II, leading to the HIV-1 transcription elongation. On the other hand, the BRD4-induced autophosphorylation of CDK9 threonine 29 is known to silence HIV-1 transcription $[59,65]$. Hence, the link between BETi functions and CDK9 phosphorylation/dephosphorylation at threonine 29 and 186 would offer another means to control HIV reactivation.

Some BETis have shown their potential to modulate immune responses and prevent inflammation and the cytokine storm, mainly through BRD4 inhibition [153,154]. Chronic inflammation still occurs during HIV-1 infection, even under antiretroviral therapy, which causes T cell exhaustion [155,156]. Interestingly, several BETis (Table 1) suppress inflammatory cytokine productions in diverse HIV-1 latency models. It will be interesting to investigate how BETis prevent $\mathrm{T}$ cell exhaustion in HIV-1 latency and contribute to host immune responses in the "Kill" step. Furthermore, BETi treatments diminish the presence of HIV-1 receptors/coreceptors in primary $\mathrm{CD}^{+} \mathrm{T}$ cell membranes but do not alter the activation marker levels, suggesting that BETis neither globally activate immune cells nor support de novo HIV-1 infection (Table 1). Despite these promising features of BETis, which could advance the "Shock and Kill" strategy-based elimination of HIV-1, it is essential to confirm the effectiveness of BETis in in vivo and in clinical trials.

$\mathrm{Li}$ and colleagues [143] first revealed that I-BET-151 efficiently reactivated HIV-1infected cells in humanized mice treated with antiretroviral drugs (Table 1). Surprisingly, this BETi only reversed HIV-1 latency in monocytic cells but not in $\mathrm{CD}^{+} \mathrm{T}$ cells, one of the principal targets of HIV-1. The authors suggested that CDK2 might disrupt I-BET-151 activity reactivating HIV-1 latency in $\mathrm{CD}^{+} \mathrm{T}$ cells, while CDK2 and CDK9 are required to promote HIV-1 transcription in monocytic cells. Another study unveiled that I-BET151 could potentially reactivate HIV- 1 from latent cell line models and primary CD4 ${ }^{+} \mathrm{T}$ cells [68]. These contradictory outcomes raise some keen questions about the role of CDK2 in HIV-1 latency and how it impacts HIV-1 transcription in $\mathrm{CD}^{+} \mathrm{T}$ cells. These findings emphasize the need for in vivo assessments of BETis. Some previous studies demonstrated that applying BETis with other LRAs (especially PKC agonists) offered greater HIV-1reactivating potentials $[68,144,145,147,150-152]$ (Table 1). Although PKC agonists induce cytokine production that can cause the cytokine storm, this problem can be overcome by the suppressive effects of BETis [147]. CPI-203 is the only BETi proved for its activity to suppress lipopolysaccharide (LPS)-stimulated inflammatory cytokines in vivo [147] but not in HIV-1-infected mice models (Table 1).

In addition to BETis listed in Table 1, MS402 and MT1 are BETis recently investigated for their cancer therapeutic potentials $[157,158]$. Although these inhibitors bind selectively to BRD4, their benefits as LRAs have not been proved. MS402 binds more selectively to BD1 than BD2 in BRD4 and prevents colitis in mice [157,159]. MT1 is an intramolecular bivalent BRD4 binder, offering higher efficacy than JQ1. Additionally, MT1 is successful in delaying leukemia progression [158]. It is worth checking out how these attractive BETis can be applied in HIV-1 reactivation and in AIDS therapy.

\section{Concluding Remarks}

The "Shock and Kill" strategy, which aims to reduce the pool reservoir, is based on the efficient reactivation of latent reservoirs, followed by the elimination of these reservoirs. Today, this strategy has shown its limits since both the "Shock" and the "Kill" steps do 
not optimally reduce the pool of reservoirs in vivo [38]. HDAC inhibitors used in the "Shock" step are the only LRAs currently tested in clinical trials but have shown multiple adverse effects in patients. The BETis, as transcriptional activators are promising LRAs that are worthwhile to test in AIDS therapy. Moreover, preliminary studies suggest that they have a positive impact on the immune system especially preventing inflammation and the cytokine storm. In vivo assessment and integrative application of BETis with other LRAs and antiretroviral drugs are the next steps required to evaluate their functions as HIV-1 LRAs.

Author Contributions: Conceptualization, T.S., C.S. and R.S.; validation, C.S.; investigation, T.S.; writing—original draft preparation, T.S.; writing—review and editing, C.S. and R.S.; visualization, T.S.; supervision, C.S. and R.S.; funding acquisition, R.S. All authors have read and agreed to the published version of the manuscript.

Funding: This research received no external funding. During preparation of the manuscript, T.S. had funding support from the Junior Science Talent Project (JSTP)-National Science and Tech-nology Development Agency, Pathumthani, Thailand, and R.S. had financial support from the UK Medical Research Council (Confidence in Concept Award: MRC/Strep POC 304737-01).

Acknowledgments: We acknowledge Nuttee Suree (Faculty of Science-Chiang Mai University) for his inspiration about BET family proteins and BETis. We appreciate the valuable coordination from Léo Meyer and Mathieu Rivalain (IUT Louis Pasteur, University of Strasbourg). Also, we are grateful to Andrea Janossy (Faculté des Sciences de la Vie-University of Strasbourg) for carefully and critically revising the language in the manuscript.

Conflicts of Interest: The authors declare no conflict of interest.

\section{References}

1. Arts, E.J.; Hazuda, D.J. HIV-1 antiretroviral drug therapy. Cold Spring Harb. Perspect. Med. 2012, 2, a007161. [CrossRef]

2. Massanella, M.; Fromentin, R.; Chomont, N. Residual inflammation and viral reservoirs: Alliance against an HIV cure. Curr. Opin. HIV AIDS 2016, 11, 234. [CrossRef] [PubMed]

3. Ait-Ammar, A.; Kula, A.; Darcis, G.; Verdikt, R.; de Wit, S.; Gautier, V.; Mallon, P.W.G.; Marcello, A.; Rohr, O.; van Lint, C. Current status of latency reversing agents facing the heterogeneity of HIV-1 cellular and tissue reservoirs. Front. Microbiol. 2020, 10, 3060. [CrossRef] [PubMed]

4. Marcello, A. Latency: The hidden HIV-1 challenge. Retrovirology 2006, 3, 7. [CrossRef]

5. García, M.; Buzón, M.J.; Benito, J.M.; Rallón, N. Peering into the HIV reservoir. Rev. Med. Virol. 2018, 28, e1981. [CrossRef]

6. Sung, J.M.; Margolis, D.M. HIV persistence on antiretroviral therapy and barriers to a cure. Adv. Exp. Med. Biol. 2018, 1075, 165-185.

7. Eisele, E.; Siliciano, R.F. Redefining the viral reservoirs that prevent HIV-1 eradication. Immunity 2012, 37, 377-388. [CrossRef]

8. Le Douce, V.; Ait-Amar, A.; Forouzanfar, F.; Fahmi, F.; Quiel, J.; El Mekdad, H.; Daouad, F.; Marban, C.; Rohr, O.; Schwartz, C. Improving combination antiretroviral therapy by targeting HIV-1 gene transcription. Expert Opin. Ther. Targets 2016, 20, 1311-1324. [CrossRef]

9. Le Douce, V.; Cherrier, T.; Riclet, R.; Rohr, O.; Schwartz, C. The many lives of CTIP2: From AIDS to cancer and cardiac hypertrophy. J. Cell. Physiol. 2014, 229, 533-537. [CrossRef]

10. Le Douce, V.; Forouzanfar, F.; Eilebrecht, S.; van Driessche, B.; Ait-Ammar, A.; Verdikt, R.; Kurashige, Y.; Marban, C.; Gautier, V.; Candolfi, E.; et al. HIC1 controls cellular- and HIV-1-gene transcription via interactions with CTIP2 and HMGA1. Sci. Rep. 2016, $6,1-14$

11. Marban, C.; Forouzanfar, F.; Ait-Ammar, A.; Fahmi, F.; El Mekdad, H.; Daouad, F.; Rohr, O.; Schwartz, C. Targeting the brain reservoirs: Toward an HIV cure. Front. Immunol. 2016, 7, 397. [CrossRef]

12. Marban, C.; Suzanne, S.; Dequiedt, F.; de Walque, S.; Redel, L.; van Lint, C.; Aunis, D.; Rohr, O. Recruitment of chromatinmodifying enzymes by CTIP2 promotes HIV-1 transcriptional silencing. EMBO J. 2007, 26, 412-423. [CrossRef]

13. Cherrier, T.; Suzanne, S.; Redel, L.; Calao, M.; Marban, C.; Samah, B.; Mukerjee, R.; Schwartz, C.; Gras, G.; Sawaya, B.E.; et al. p21 ${ }^{\mathrm{WAF} 1}$ gene promoter is epigenetically silenced by CTIP2 and SUV39H1. Oncogene 2009, 28, 3380-3389. [CrossRef] [PubMed]

14. Le Douce, V.; Colin, L.; Redel, L.; Cherrier, T.; Herbein, G.; Aunis, D.; Rohr, O.; van Lint, C.; Schwartz, C. LSD1 cooperates with CTIP2 to promote HIV-1 transcriptional silencing. Nucleic Acids Res. 2012, 40, 1904-1915. [CrossRef] [PubMed]

15. Cherrier, T.; Le Douce, V.; Eilebrecht, S.; Riclet, R.; Marban, C.; Dequiedt, F.; Goumon, Y.; Paillart, J.C.; Mericskay, M.; Parlakian, A.; et al. CTIP2 is a negative regulator of P-TEFb. Proc. Natl. Acad. Sci. USA 2013, 110, 12655-12660. [CrossRef]

16. Eilebrecht, S.; Le Douce, V.; Riclet, R.; Targat, B.; Hallay, H.; van Driessche, B.; Schwartz, C.; Robette, G.; van Lint, C.; Rohr, O.; et al. HMGA1 recruits CTIP2-repressed P-TEFb to the HIV-1 and cellular target promoters. Nucleic Acids Res. 2014, 42, $4962-4971$. [CrossRef] 
17. Darcis, G.; van Driessche, B.; van Lint, C. HIV latency: Should we shock or lock? Trends Immunol. 2017, 38, 217-228. [CrossRef]

18. Elsheikh, M.M.; Tang, Y.; Li, D.; Jiang, G. Deep latency: A new insight into a functional HIV cure. EBioMedicine 2019, 45, 624-629. [CrossRef]

19. Mousseau, G.; Aneja, R.; Clementz, M.A.; Mediouni, S.; Lima, N.S.; Haregot, A.; Kessing, C.F.; Jablonski, J.A.; Thenin-Houssier, S.; Nagarsheth, N.; et al. Resistance to the Tat inhibitor didehydro-cortistatin A is mediated by heightened basal HIV-1 transcription. mBio 2019, 10, e01750-18. [CrossRef] [PubMed]

20. Planas, D.; Pagliuzza, A.; Ponte, R.; Fert, A.; Marchand, L.R.; Massanella, M.; Gosselin, A.; Mehraj, V.; Dupuy, F.P.; Isnard, S.; et al. LILAC pilot study: Effects of metformin on mTOR activation and HIV reservoir persistence during antiretroviral therapy. EBioMedicine 2021, 65, 103270. [CrossRef] [PubMed]

21. Rohr, O. Flower power: Locking HIV in the gut with French lilac. EBioMedicine 2021, 66, 103299. [CrossRef]

22. Schwartz, C.; Bouchat, S.; Marban, C.; Gautier, V.; van Lint, C.; Rohr, O.; Le Douce, V. On the way to find a cure: Purging latent HIV-1 reservoirs. Biochem. Pharmacol. 2017, 146, 10-22. [CrossRef]

23. White, C.H.; Johnston, H.E.; Moesker, B.; Manousopoulou, A.; Margolis, D.M.; Richman, D.D.; Spina, C.A.; Garbis, S.D.; Woelk, C.H.; Beliakova-Bethell, N. Mixed effects of suberoylanilide hydroxamic acid (SAHA) on the host transcriptome and proteome and their implications for HIV reactivation from latency. Antiviral. Res. 2015, 123, 78-85. [CrossRef]

24. Jeng, M.Y.; Ali, I.; Ott, M. Manipulation of the host protein acetylation network by human immunodeficiency virus type 1. Crit. Rev. Biochem. Mol. Biol. 2015, 50, 314-325.

25. Van Lint, C.; Emiliani, S.; Ott, M.; Verdin, E. Transcriptional activation and chromatin remodeling of the HIV-1 promoter in response to histone acetylation. EMBO J. 1996, 15, 1112-1120. [CrossRef]

26. Quivy, V.; van Lint, C. Diversity of acetylation targets and roles in transcriptional regulation: The human immunodeficiency virus type 1 promoter as a model system. Biochem. Pharmacol. 2002, 64, 925-934. [CrossRef]

27. Reuse, S.; Calao, M.; Kabeya, K.; Guiguen, A.; Gatot, J.S.; Quivy, V.; Vanhulle, C.; Lamine, A.; Vaira, D.; Demonte, D.; et al. Synergistic activation of HIV-1 expression by deacetylase inhibitors and prostratin: Implications for treatment of latent infection. PLoS ONE 2009, 4, e6093. [CrossRef] [PubMed]

28. Bouchat, S.; Delacourt, N.; Kula, A.; Darcis, G.; van Driessche, B.; Corazza, F.; Gatot, J.S.; Melard, A.; Vanhulle, C.; Kabeya, K.; et al. Sequential treatment with 5-aza-2'-deoxycytidine and deacetylase inhibitors reactivates HIV-1. EMBO Mol. Med. 2016, 8, 117-138. [CrossRef] [PubMed]

29. Bouchat, S.; Gatot, J.S.; Kabeya, K.; Cardona, C.; Colin, L.; Herbein, G.; de Wit, S.; Clumeck, N.; Lambotte, O.; Rouzioux, C.; et al. Histone methyltransferase inhibitors induce HIV-1 recovery in resting CD4 ${ }^{+} \mathrm{T}$ cells from HIV-1-infected HAART-treated patients. AIDS 2012, 26, 1473-1482. [CrossRef] [PubMed]

30. Subramanian, S.; Bates, S.E.; Wright, J.J.; Espinoza-Delgado, I.; Piekarz, R.L. Clinical toxicities of histone deacetylase inhibitors. Pharmaceuticals 2010, 3, 2751-2767. [CrossRef]

31. Barboric, M.; Nissen, R.M.; Kanazawa, S.; Jabrane-Ferrat, N.; Peterlin, B.M. NF-kB binds P-TEFb to stimulate transcriptional elongation by RNA polymerase II. Mol. Cell 2001, 8, 327-337. [CrossRef]

32. Jiang, G.; Dandekar, S. Targeting NF- $\mathrm{B}$ signaling with protein kinase C agonists as an emerging strategy for combating HIV latency. AIDS Res. Hum. Retrovir. 2015, 31, 4-12. [CrossRef] [PubMed]

33. Rice, A.P. Cyclin-dependent kinases as therapeutic targets for HIV-1 infection. Expert Opin. Ther. Targets 2016, 20 , 1453-1461. [CrossRef]

34. Sung, T.L.; Rice, A.P. Effects of prostratin on cyclin T1/P-TEFb function and the gene expression profile in primary resting CD4 ${ }^{+}$ T cells. Retrovirology 2006, 3, 66. [CrossRef]

35. Fujinaga, K.; Barboric, M.; Li, Q.; Luo, Z.; Price, D.H.; Peterlin, B.M. PKC phosphorylates HEXIM1 and regulates P-TEFb activity. Nucleic Acids Res. 2012, 40, 9160-9170. [CrossRef] [PubMed]

36. Pandeló José, D.; Bartholomeeusen, K.; da Cunha, R.D.; Abreu, C.M.; Glinski, J.; da Costa, T.B.; Bacchi Rabay, A.F.; Pianowski Filho, L.F.; Dudycz, L.W.; Ranga, U.; et al. Reactivation of latent HIV-1 by new semi-synthetic ingenol esters. Virology 2014, 462-463, 328-339. [CrossRef] [PubMed]

37. Darcis, G.; Kula, A.; Bouchat, S.; Fujinaga, K.; Corazza, F.; Ait-Ammar, A.; Delacourt, N.; Melard, A.; Kabeya, K.; Vanhulle, C.; et al . An in-depth comparison of latency-reversing agent combinations in various in vitro and ex vivo HIV-1 latency models identified bryostatin-1+JQ1 and ingenol-B+JQ1 to potently reactivate viral gene expression. PLoS Pathog. 2015, 11, e1005063. [CrossRef] [PubMed]

38. Abner, E.; Jordan, A. HIV "shock and kill" therapy: In need of revision. Antiviral Res. 2019, 166, 19-34. [CrossRef]

39. Cary, D.C.; Fujinaga, K.; Peterlin, B.M. Molecular mechanisms of HIV latency. J. Clin. Investig. 2016, 126, 448-454. [CrossRef] [PubMed]

40. Darcis, G.; van Driessche, B.; van Lint, C. Preclinical shock strategies to reactivate latent HIV-1: An update. Curr. Opin. HIV AIDS 2016, 11, 388-393. [CrossRef]

41. van Lint, C.; Bouchat, S.; Marcello, A. HIV-1 transcription and latency: An update. Retrovirology 2013, 10, 67. [CrossRef] [PubMed]

42. Ait-Ammar, A.; Bellefroid, M.; Daouad, F.; Martinelli, V.; van Assche, J.; Wallet, C.; Rodari, A.; de Rovere, M.; Fahrenkrog, B.; Schwartz, C.; et al. Inhibition of HIV-1 gene transcription by KAP1 in myeloid lineage. Sci. Rep. 2021, 11, 2692. [CrossRef] 
43. Deeks, S.G.; Lewin, S.R.; Ross, A.L.; Ananworanich, J.; Benkirane, M.; Cannon, P.; Chomont, N.; Douek, D.; Lifson, J.D.; Lo, Y.R.; et al. International AIDS Society global scientific strategy: Towards an HIV cure 2016. Nat. Med. 2016, 22, 839-850. [CrossRef]

44. Le Douce, V.; Janossy, A.; Hallay, H.; Ali, S.; Riclet, R.; Rohr, O.; Schwartz, C. Achieving a cure for HIV infection: Do we have reasons to be optimistic? J. Antimicrob. Chemother. 2012, 67, 1063-1074. [CrossRef] [PubMed]

45. Filippakopoulos, P.; Qi, J.; Picaud, S.; Shen, Y.; Smith, W.B.; Fedorov, O.; Morse, E.M.; Keates, T.; Hickman, T.T.; Felletar, I.; et al. Selective inhibition of BET bromodomains. Nature 2010, 468, 1067-1073. [CrossRef] [PubMed]

46. Nicodeme, E.; Jeffrey, K.L.; Schaefer, U.; Beinke, S.; Dewell, S.; Chung, C.W.; Chandwani, R.; Marazzi, I.; Wilson, P.; Coste, H.; et al. Suppression of inflammation by a syn-thetic histone mimic. Nature 2010, 468, 1119-1123. [CrossRef]

47. Padmanabhan, B.; Mathur, S.; Manjula, R.; Tripathi, S. Bromodomain and extra-terminal (BET) family proteins: New thera-peutic targets in major diseases. J. Biosci. 2016, 41, 295-311. [CrossRef]

48. Banerjee, C.; Archin, N.; Michaels, D.; Belkina, A.C.; Denis, G.V.; Bradner, J.; Sebastiani, P.; Margolis, D.M.; Montano, M. BET bromodomain inhibition as a novel strategy for reactivation of HIV-1. J. Leukoc. Biol. 2012, 92, 1147-1154. [CrossRef]

49. Zhu, J.; Gaiha, G.D.; John, S.P.; Pertel, T.; Chin, C.R.; Gao, G.; Qu, H.; Walker, B.D.; Elledge, S.J.; Brass, A.L. Reactivation of latent HIV-1 by inhibition of BRD4. Cell Rep. 2012, 2, 807-816. [CrossRef]

50. Yang, A.Y.; Kim, H.; Li, W.; Kong, A.N. Natural compound-derived epigenetic regulators targeting epigenetic readers, writers and erasers. Curr. Top. Med. Chem. 2016, 16, 697-713. [CrossRef]

51. Huang, B.; Li, G.; Jiang, X.H. Fate determination in mesenchymal stem cells: A perspective from histone-modifying enzymes. Stem Cell Res. Ther. 2015, 6, 35. [CrossRef]

52. Lusic, M.; Siliciano, R.F. Nuclear landscape of HIV-1 infection and integration. Nat. Rev. Microbiol. 2017, 15, 69-82. [CrossRef]

53. Lange, U.C.; Verdikt, R.; Ait-Ammar, A.; van Lint, C. Epigenetic crosstalk in chronic infection with HIV-1. Semin. Immunopathol. 2020, 42, 187-200. [CrossRef]

54. Du Chéné, I.; Basyuk, E.; Lin, Y.L.; Triboulet, R.; Knezevich, A.; Chable-Bessia, C.; Mettling, C.; Baillat, V.; Reynes, J.; Corbeau, P.; et al. Suv39H1 and HP1 $\gamma$ are responsible for chromatin-mediated HIV-1 transcriptional silencing and post-integration latency. EMBO J. 2007, 26, 424-435. [CrossRef]

55. Taniguchi, Y. The bromodomain and extra-terminal domain (BET) family: Functional anatomy of BET paralogous proteins. Int. J. Mol. Sci. 2016, 17, 1849. [CrossRef] [PubMed]

56. Sartor, G.C.; Malvezzi, A.M.; Kumar, A.; Andrade, N.S.; Wiedner, H.J.; Vilca, S.J.; Janczura, K.J.; Bagheri, A.; Al-Ali, H.; Powell, S.K.; et al. Enhancement of BDNF expression and memory by HDAC inhibition requires BET bromodomain reader proteins. J. Neurosci. 2019, 39, 612-626. [CrossRef] [PubMed]

57. Boehm, D.; Conrad, R.J.; Ott, M. Bromodomain proteins in HIV infection. Viruses 2013, 5, 1571-1586. [CrossRef] [PubMed]

58. Huang, B.; Yang, X.D.; Zhou, M.M.; Ozato, K.; Chen, L.F. Brd4 coactivates transcriptional activation of NF-kB via specific binding to acetylated RelA. Mol. Cell. Biol. 2009, 29, 1375-1387. [CrossRef] [PubMed]

59. Yang, Z.; Yik, J.H.; Chen, R.; He, N.; Jang, M.K.; Ozato, K.; Zhou, Q. Recruitment of P-TEFb for stimulation of transcriptional elongation by the bromodomain protein Brd4. Mol. Cell 2005, 19, 535-545. [CrossRef] [PubMed]

60. Bisgrove, D.A.; Mahmoudi, T.; Henklein, P.; Verdin, E. Conserved P-TEFb-interacting domain of BRD4 inhibits HIV transcription. Proc. Natl. Acad. Sci. USA 2007, 104, 13690-13695. [CrossRef] [PubMed]

61. Jang, M.K.; Mochizuki, K.; Zhou, M.; Jeong, H.S.; Brady, J.N.; Ozato, K. The bromodomain protein Brd4 is a positive regulatory component of P-TEFb and stimulates RNA polymerase II-dependent transcription. Mol. Cell 2005, 19, 523-534. [CrossRef] [PubMed]

62. Yang, Z.; Zhu, Q.; Luo, K.; Zhou, Q. The 7SK small nuclear RNA inhibits the CDK9/cyclin T1 kinase to control transcription. Nature 2001, 414, 317-322. [CrossRef]

63. Schröder, S.; Cho, S.; Zeng, L.; Zhang, Q.; Kaehlcke, K.; Mak, L.; Lau, J.; Bisgrove, D.; Schnölzer, M.; Verdin, E.; et al. Twopronged binding with bromodomain-containing protein 4 liberates positive transcription elongation factor $b$ from inactive ribonucleoprotein complexes. J. Biol. Chem. 2012, 287, 1090-1099. [CrossRef]

64. Li, Z.; Guo, J.; Wu, Y.; Zhou, Q. The BET bromodomain inhibitor JQ1 activates HIV latency through antagonizing Brd4 inhibition of Tat-transactivation. Nucleic Acids Res. 2013, 41, 277-287. [CrossRef]

65. Zhou, M.; Huang, K.; Jung, K.J.; Cho, W.K.; Klase, Z.; Kashanchi, F.; Pise-Masison, C.A.; Brady, J.N. Bromodomain protein Brd4 regulates human immunodeficiency virus transcription through phosphorylation of CDK9 at threonine 29. J. Virol. 2009, 83, 1036-1044. [CrossRef] [PubMed]

66. Wallet, C.; Rohr, O.; Schwartz, C. Evolution of a concept: From accessory protein to key virulence factor, the case of HIV-1 Vpr. Biochem. Pharmacol. 2020, 180, 114128. [CrossRef]

67. Wang, J.; Reuschel, E.L.; Shackelford, J.M.; Jeang, L.; Shivers, D.K.; Diehl, J.A.; Yu, X.-F.; Finkel, T.H. HIV-1 Vif promotes the G1-to S-phase cell-cycle transition. Blood 2011, 117, 1260-1269. [CrossRef] [PubMed]

68. Boehm, D.; Calvanese, V.; Dar, R.D.; Xing, S.; Schroeder, S.; Martins, L.; Aull, K.; Li, P.C.; Planelles, V.; Bradner, J.E.; et al. BET bromodomain-targeting compounds reactivate HIV from latency via a Tat-independent mechanism. Cell Cycle 2013, 12, 452-462. [CrossRef] [PubMed]

69. Conrad, R.J.; Fozouni, P.; Thomas, S.; Sy, H.; Zhang, Q.; Zhou, M.M.; Ott, M. The short isoform of BRD4 promotes HIV-1 latency by engaging repressive SWI/SNF chromatin-remodeling complexes. Mol. Cell 2017, 67, 1001-1012. [CrossRef] 
70. Alamer, E.; Zhong, C.; Hajnik, R.; Soong, L.; Hu, H. Modulation of BRD4 in HIV epigenetic regulation: Implications for finding an HIV cure. Retrovirology 2021, 18, 3. [CrossRef]

71. Lu, P.; Qu, X.; Shen, Y.; Jiang, Z.; Wang, P.; Zeng, H.; Ji, H.; Deng, J.; Yang, X.; Li, X.; et al. The BET inhibitor OTX015 reac-tivates latent HIV-1 through P-TEFb. Sci. Rep. 2016, 6, 1-13.

72. Beck, S.; Hanson, I.; Kelly, A.; Pappin, D.J.; Trowsdale, J. A homologue of the Drosophila female sterile homeotic (fsh) gene in the class II region of the human MHC. DNA Sequence 1992, 2, 203-210. [CrossRef] [PubMed]

73. Malovannaya, A.; Lanz, R.B.; Jung, S.Y.; Bulynko, Y.; Le, N.T.; Chan, D.W.; Ding, C.; Shi, Y.; Yucer, N.; Krenciute, G.; et al. Analysis of the human endogenous coregulator complexome. Cell 2011, 145, 787-799. [CrossRef] [PubMed]

74. Denis, G.V.; McComb, M.E.; Faller, D.V.; Sinha, A.; Romesser, P.B.; Costello, C.E. Identification of transcription complexes that contain the double bromodomain protein Brd2 and chromatin remodeling machines. J. Proteome Res. 2006, 5, 502-511. [CrossRef]

75. Kundu, S.K.; Katzenstein, D.; Valentine, F.T.; Spino, C.; Efron, B.; Merigan, T.C. Effect of therapeutic immunization with recombinant gp160 HIV-1 vaccine on HIV-1 proviral DNA and plasma RNA: Relationship to cellular immune responses. J. Acquir. Immune Defic. Syndr. 1997, 15, 269-274. [CrossRef]

76. Karn, J. A new BET on the control of HIV latency. Cell Cycle 2013, 12, 545-546. [CrossRef]

77. Hsu, S.C.; Gilgenast, T.G.; Bartman, C.R.; Edwards, C.R.; Stonestrom, A.J.; Huang, P.; Emerson, D.J.; Evans, P.; Werner, M.T.; Keller, C.A.; et al. The BET protein BRD2 cooperates with CTCF to enforce transcriptional and architectural boundaries. Mol. Cell 2017, 66, 102-116. [CrossRef]

78. Li, Y.; Li, G.; Ivanova, A.; Aaron, S.; Simm, M. The critical role of human transcriptional repressor CTCF mRNA up-regulation in the induction of anti-HIV-1 responses in CD4 ${ }^{+}$T cells. Immunol. Lett. 2008, 117, 35-44. [CrossRef] [PubMed]

79. Roberts, T.C.; Etxaniz, U.; Dall'Agnese, A.; Wu, S.Y.; Chiang, C.M.; Brennan, P.E.; Wood, M.J.A.; Puri, P.L. BRD3 and BRD4 BET bromodomain proteins differentially regulate skeletal myogenesis. Sci. Rep. 2017, 7, 1-16.

80. LeRoy, G.; Rickards, B.; Flint, S.J. The double bromodomain proteins Brd2 and Brd3 couple histone acetylation to transcription. Mol. Cell 2008, 30, 51-60. [CrossRef] [PubMed]

81. Gamsjaeger, R.; Webb, S.R.; Lamonica, J.M.; Billin, A.; Blobel, G.A.; Mackay, J.P. Structural basis and specificity of acetylated transcription factor GATA1 recognition by BET family bromodomain protein Brd3. Mol. Cell. Biol. 2011, 31, 2632-2640. [CrossRef]

82. Ren, W.; Wang, C.; Wang, Q.; Zhao, D.; Zhao, K.; Sun, D.; Liu, X.; Han, C.; Hou, J.; Li, X.; et al. Bromodomain protein Brd3 promotes Ifnb1 transcription via enhancing IRF3/p300 complex formation and recruitment to Ifnb1 promoter in macrophages. Sci. Rep. 2017, 7, 39986. [CrossRef]

83. Hsu, S.C.; Blobel, G.A. The role of bromodomain and extraterminal motif (BET) proteins in chromatin structure. Cold Spring Harb. Symp. Quant. Biol. 2017, 82, 37-43. [CrossRef]

84. Govin, J.; Lestrat, C.; Caron, C.; Pivot-Pajot, C.; Rousseaux, S.; Khochbin, S. Histone acetylation-mediated chromatin com-paction during mouse spermatogenesis. In The Histone Code and Beyond; Springer: Berlin, Germany, 2006; pp. 155-172.

85. Bourova-Flin, E.; Chuffart, F.; Rousseaux, S.; Khochbin, S. The role of bromodomain testis-specific factor, BRDT, in cancer: A biomarker and a possible therapeutic target. Cell J. 2017, 19, 1-8. [PubMed]

86. Chang, J.J.; Altfeld, M. Innate immune activation in primary HIV-1 infection. J. Infect. Dis. 2010, 202 (Suppl. 2), S297-S301. [CrossRef] [PubMed]

87. Iwasaki, A. Innate immune recognition of HIV-1. Immunity 2012, 37, 389-398. [CrossRef] [PubMed]

88. Sumner, R.P.; Thorne, L.G.; Fink, D.L.; Khan, H.; Milne, R.S.; Towers, G.J. Are evolution and the intracellular innate immune system key determinants in HIV transmission? Front. Immunol. 2017, 8, 1246. [CrossRef]

89. Wang, N.; Wu, R.; Tang, D.; Kang, R. The BET family in immunity and disease. Signal Transduct. Target. Ther. 2021, 6, 1-22.

90. Wainstein, M.V.; Mossmann, M.; Araujo, G.N.; Gonçalves, S.C.; Gravina, G.L.; Sangalli, M.; Veadrigo, F.; Matte, R.; Reich, R.; Costa, F.G.; et al. Elevated serum interleukin- 6 is predictive of coronary artery disease in intermediate risk overweight patients referred for coronary angiography. Diabetol. Metab. Syndr. 2017, 9, 1-7. [CrossRef]

91. Freeman, M.L.; Shive, C.L.; Nguyen, T.P.; Younes, S.A.; Panigrahi, S.; Lederman, M.M. Cytokines and T-cell homeostasis in HIV infection. J. Infect. Dis. 2016, 214 (Suppl. 2), S51-S57. [CrossRef]

92. Borges, Á.H.; O’Connor, J.L.; Phillips, A.N.; Rönsholt, F.F.; Pett, S.; Vjecha, M.J.; French, M.A.; Lundgren, J.D. Factors associated with plasma IL-6 levels during HIV infection. J. Infect. Dis. 2015, 212, 585-595. [CrossRef]

93. Keating, S.M.; Golub, E.T.; Nowicki, M.; Young, M.; Anastos, K.; Crystal, H.; Cohen, M.H.; Zhang, J.; Greenblatt, R.M.; Desai, S.; et al. The effect of HIV infection and HAART on inflammatory biomarkers in a population-based cohort of US women. AIDS 2011, 25, 1823-1832. [CrossRef]

94. Muema, D.M.; Akilimali, N.A.; Ndumnego, O.C.; Rasehlo, S.S.; Durgiah, R.; Ojwach, D.B.; Ismail, N.; Dong, K.L.; Ndhlovu, Z.M.; Mabuka, J.M.; et al. Association between the cytokine storm, immune cell dynamics, and viral replicative capacity in hyperacute HIV infection. BMC Med. 2020, 18, 1-17. [CrossRef] [PubMed]

95. Akase, I.E.; Obiako, R.O.; Musa, B.O.; Opawoye, A.; Akanmu, A.S. Levels of interleukin 6 and 10 and their relationship to hematological changes in HIV treatment-naïve and treatment-experienced patients. Sub-Saharan Afr. J. Med. 2019, 6, 90-95. [CrossRef]

96. Parameswaran, N.; Patial, S. Tumor necrosis factor- $\alpha$ signaling in macrophages. Crit. Rev. Eukaryot. Gene Expr. 2010, 20, 87-103. [CrossRef] 
97. Tenorio, A.R.; Zheng, Y.; Bosch, R.J.; Krishnan, S.; Rodriguez, B.; Hunt, P.W.; Plants, J.; Seth, A.; Wilson, C.C.; Deeks, S.G.; et al. Soluble markers of inflammation and coagulation but not T-cell activation predict non-AIDS-defining morbid events during suppressive antiretroviral treatment. J. Infect. Dis. 2014, 210, 1248-1259. [CrossRef]

98. Kuller, L.H.; Tracy, R.; Belloso, W.; de Wit, S.; Drummond, F.; Lane, H.C.; Ledergerber, B.; Lundgren, J.; Neuhaus, J.; Nixon, D.; et al. Inflammatory and coagulation biomarkers and mortality in patients with HIV infection. PLoS Med. 2008, 5, e203. [CrossRef]

99. Maksylewicz, A.; Bysiek, A.; Lagosz, K.B.; Macina, J.M.; Kantorowicz, M.; Bereta, G.; Sochalska, M.; Gawron, K.; ChomyszynGajewska, M.; Potempa, J.; et al. BET bromodomain inhibitors suppress inflammatory activation of gingival fibroblasts and epithelial cells from periodontitis patients. Front. Immunol. 2019, 10, 933. [CrossRef]

100. Nguyen, T.H.; Maltby, S.; Eyers, F.; Foster, P.S.; Yang, M. Bromodomain and extra terminal (BET) inhibitor suppresses macrophagedriven steroid-resistant exacerbations of airway hyper-responsiveness and inflammation. PLoS ONE 2016, 11, e0163392. [CrossRef] [PubMed]

101. Jahagirdar, R.; Zhang, H.; Azhar, S.; Tobin, J.; Attwell, S.; Yu, R.; Wu, J.; McLure, K.G.; Hansen, H.C.; Wagner, G.S.; et al. A novel BET bromodomain inhibitor, RVX-208, shows reduction of atherosclerosis in hyperlipidemic ApoE deficient mice. Atherosclerosis 2014, 236, 91-100. [CrossRef] [PubMed]

102. Belkina, A.C.; Nikolajczyk, B.S.; Denis, G.V. BET protein function is required for inflammation: Brd2 genetic disruption and BET inhibitor JQ1 impair mouse macrophage inflammatory responses. J. Immunol. 2013, 190, 3670-3678. [CrossRef]

103. Remke, N.; Bisht, S.; Oberbeck, S.; Nolting, J.; Brossart, P. Selective BET-bromodomain inhibition by JQ1 suppresses dendritic cell maturation and antigen-specific T-cell responses. Cancer Immunol. Immunother. 2021, 70, 107-121. [CrossRef]

104. Schilderink, R.; Bell, M.; Reginato, E.; Patten, C.; Rioja, I.; Hilbers, F.W.; Kabala, P.A.; Reedquist, K.A.; Tough, D.F.; Tak, P.P.; et al. BET bromodomain inhibition reduces maturation and enhances tolerogenic properties of human and mouse dendritic cells. Mol. Immunol. 2016, 79, 66-76. [CrossRef]

105. Saravia, J.; Chapman, N.M.; Chi, H. Helper T cell differentiation. Cell. Mol. Immunol. 2019, 16, 634-643. [CrossRef] [PubMed]

106. Guglani, L.; Khader, S.A. Th17 cytokines in mucosal immunity and inflammation. Curr. Opin. HIV AIDS 2010, 5, 120-127. [CrossRef] [PubMed]

107. Gibbons, H.R.; Mi, D.J.; Farley, V.M.; Esmond, T.; Kaood, M.B.; Aune, T.M. Bromodomain inhibitor JQ1 reversibly blocks IFN- $\gamma$ production. Sci. Rep. 2019, 9, 1-10. [CrossRef]

108. Watanabe, D.; Uehira, T.; Suzuki, S.; Matsumoto, E.; Ueji, T.; Hirota, K.; Minami, R.; Takahama, S.; Hayashi, K.; Sawamura, M.; et al. Clinical characteristics of HIV-1-infected patients with high levels of plasma interferon- $\gamma$ : A multicenter observational study. BMC Infect. Dis. 2019, 19, 1-10. [CrossRef]

109. Roff, S.R.; Song, E.N.; Yamamoto, J.K. The significance of interferon- $\gamma$ in HIV-1 pathogenesis, therapy, and prophylaxis. Front. Immunol. 2014, 4, 498. [CrossRef] [PubMed]

110. Nakayama, T.; Yamashita, M. Initiation and maintenance of Th2 cell identity. Curr. Opin. Immunol. 2008, 20, 265-271. [CrossRef]

111. Malhotra, P.; Haslett, P.; Sherry, B.; Shepp, D.H.; Barber, P.; Abshier, J.; Roy, U.; Schmidtmayerova, H. Increased plasma levels of the TH2 chemokine CCL18 associated with low CD4 ${ }^{+}$T cell counts in HIV-1-infected patients with a suppressed viral load. Sci. Rep. 2019, 9, 1-8. [CrossRef]

112. Planas, D.; Routy, J.P.; Ancuta, P. New Th17-specific therapeutic strategies for HIV remission. Curr. Opin. HIV AIDS 2019, 14, 85-92. [CrossRef] [PubMed]

113. Bixler, S.L.; Mattapallil, J.J. Loss and dysregulation of Th17 cells during HIV infection. Clin. Dev. Immunol. 2013, 2013. [CrossRef]

114. de Araújo, E.F.; Feriotti, C.; Galdino, N.A.D.L.; Preite, N.W.; Calich, V.L.G.; Loures, F.V. The iDO-ahr axis controls Th17/Treg immunity in a pulmonary model of fungal infection. Front. Immunol. 2017, 8, 880. [CrossRef] [PubMed]

115. Tian, C.Q.; Chen, L.; Chen, H.D.; Huan, X.J.; Hu, J.P.; Shen, J.K.; Xiong, B.; Wang, Y.Q.; Miao, Z.H. Inhibition of the BET family reduces its new target gene IDO1 expression and the production of L-kynurenine. Cell Death Dis. 2019, 10, 1-13. [CrossRef]

116. Cheung, K.L.; Zhang, F.; Jaganathan, A.; Sharma, R.; Zhang, Q.; Konuma, T.; Shen, T.; Lee, J.Y.; Ren, C.; Chen, C.H.; et al. Distinct roles of Brd2 and Brd4 in potentiating the transcriptional program for Th17 cell differentiation. Mol. Cell 2017, 65, 1068-1080. [CrossRef]

117. Ghosh, S.; Lora, J.M. Suppression of TH17-mediated pathology through BET bromodomain inhibition. Drug Discov. Today Technol. 2016, 19, 39-44. [CrossRef]

118. Mele, D.A.; Salmeron, A.; Ghosh, S.; Huang, H.R.; Bryant, B.M.; Lora, J.M. BET bromodomain inhibition suppresses TH17mediated pathology. J. Exp. Med. 2013, 210, 2181-2190. [CrossRef] [PubMed]

119. Rocco, J.; Mellors, J.W.; Macatangay, B.J. Regulatory T cells: The ultimate HIV reservoir? J. Virus Erad. 2018, 4, 209-214. [CrossRef]

120. Abdel-Hameed, E.A.; Ji, H.; Sherman, K.E.; Shata, M.T.M. Epigenetic modification of FOXP3 in patients with chronic HIV infection. J. Acquir. Immune Defic. Syndr. 2014, 65, 19. [CrossRef]

121. Grant, C.; Oh, U.; Fugo, K.; Takenouchi, N.; Griffith, C.; Yao, K.; Newhook, T.E.; Ratner, L.; Jacobson, S. Foxp3 represses retroviral transcription by targeting both NF-KB and CREB pathways. PLoS Pathog. 2006, 2, e33. [CrossRef]

122. Kint, S.; Trypsteen, W.; De Spiegelaere, W.; Malatinkova, E.; Kinloch-de Loes, S.; De Meyer, T.; Van Criekinge, W.; Vandekerckhove, L. Underestimated effect of intragenic HIV-1 DNA methylation on viral transcription in infected individuals. Clin. Epigenetics 2020, 12, 1-11. [CrossRef] [PubMed] 
123. Adeegbe, D.O.; Liu, S.; Hattersley, M.M.; Bowden, M.; Zhou, C.W.; Li, S.; Vlahos, R.; Grondine, M.; Dolgalev, I.; Ivanova, E.V.; et al. BET Bromodomain inhibition cooperates with PD-1 blockade to facilitate antitumor response in Kras-mutant non-small cell lung cancer. Cancer Immunol. Res. 2018, 6, 1234-1245. [CrossRef] [PubMed]

124. Collins, D.R.; Gaiha, G.D.; Walker, B.D. CD8 ${ }^{+}$T cells in HIV control, cure and prevention. Nat. Rev. Immunol. 2020, 20, 471-482. [CrossRef]

125. Gulzar, N.; Copeland, K.F. CD8 ${ }^{+}$T-cells: Function and response to HIV infection. Curr. HIV Res. 2004, 2, 23-37. [CrossRef]

126. Georgiev, P.; Wang, Y.; Muise, E.S.; Bandi, M.L.; Blumenschein, W.; Sathe, M.; Pinheiro, E.M.; Shumway, S.D. BET bromodomain inhibition suppresses human T cell function. Immunohorizons 2019, 3, 294-305. [CrossRef]

127. Gegonne, A.; Chen, Q.R.; Dey, A.; Etzensperger, R.; Tai, X.; Singer, A.; Meerzaman, D.; Ozato, K.; Singer, D.S. Immature CD8 single-positive thymocytes are a molecularly distinct subpopulation, selectively dependent on BRD4 for their differentiation. Cell Rep. 2018, 24, 117-129. [CrossRef]

128. Kagoya, Y.; Nakatsugawa, M.; Yamashita, Y.; Ochi, T.; Guo, T.; Anczurowski, M.; Saso, K.; Butler, M.O.; Arrowsmith, C.H.; Hirano, $\mathrm{N}$. BET bromodomain inhibition enhances $\mathrm{T}$ cell persistence and function in adoptive immunotherapy models. J. Clin. Investig. 2016, 126, 3479-3494. [CrossRef] [PubMed]

129. Fenwick, C.; Joo, V.; Jacquier, P.; Noto, A.; Banga, R.; Perreau, M.; Pantaleo, G. T-cell exhaustion in HIV infection. Immunol. Rev. 2019, 292, 149-163. [CrossRef]

130. Saeidi, A.; Zandi, K.; Cheok, Y.Y.; Saeidi, H.; Wong, W.F.; Lee, C.Y.Q.; Cheong, H.C.; Yong, Y.K.; Larsson, M.; Shankar, E.M. T-cell exhaustion in chronic infections: Reversing the state of exhaustion and reinvigorating optimal protective immune responses. Front. Immunol. 2018, 9, 2569. [CrossRef] [PubMed]

131. Jing, X.; Shao, S.; Zhang, Y.; Luo, A.; Zhao, L.; Zhang, L.; Gu, S.; Zhao, X. BRD4 inhibition suppresses PD-L1 expression in triple-negative breast cancer. Exp. Cell Res. 2020, 392, 112034. [CrossRef] [PubMed]

132. Zhu, H.; Bengsch, F.; Svoronos, N.; Rutkowski, M.R.; Bitler, B.G.; Allegrezza, M.J.; Yokoyama, Y.; Kossenkov, A.V.; Bradner, J.E.; Conejo-Garcia, J.R.; et al. BET bromodomain inhibition promotes anti-tumor immunity by suppressing PD-L1 expression. Cell Rep. 2016, 16, 2829-2837. [CrossRef]

133. Moir, S.; Fauci, A.S. B-cell responses to HIV infection. Immunol. Rev. 2017, 275, 33-48. [CrossRef] [PubMed]

134. Zabel, F.; Mohanan, D.; Bessa, J.; Link, A.; Fettelschoss, A.; Saudan, P.; Kündig, T.M.; Bachmann, M.F. Viral particles drive rapid differentiation of memory B cells into secondary plasma cells producing increased levels of antibodies. J. Immunol. 2014, 192, 5499-5508. [CrossRef] [PubMed]

135. Mouquet, H. Antibody B cell responses in HIV-1 infection. Trends Immunol. 2014, 35, 549-561. [CrossRef]

136. Li, X.; Baek, G.; Ramanand, S.G.; Sharp, A.; Gao, Y.; Yuan, W.; Welti, J.; Rodrigues, D.N.; Dolling, D.; Figueiredo, I.; et al. BRD4 promotes DNA repair and mediates the formation of TMPRSS2-ERG gene rearrangements in prostate cancer. Cell Rep. 2018, 22, 796-808. [CrossRef] [PubMed]

137. Stanlie, A.; Yousif, A.S.; Akiyama, H.; Honjo, T.; Begum, N.A. Chromatin reader Brd4 functions in Ig class switching as a repair complex adaptor of nonhomologous end-joining. Mol. Cell 2014, 55, 97-110. [CrossRef]

138. Schormann, N.; Ricciardi, R.; Chattopadhyay, D. Uracil-DNA glycosylases-Structural and functional perspectives on an essential family of DNA repair enzymes. Protein Sci. 2014, 23, 1667-1685. [CrossRef]

139. Ward, I.M.; Minn, K.; van Deursen, J.; Chen, J. p53 Binding protein 53BP1 is required for DNA damage responses and tumor suppression in mice. Mol. Cell. Biol. 2003, 23, 2556-2563. [CrossRef]

140. Shim, J.M.; Lee, J.S.; Russell, K.E.; Wiegman, C.H.; Barnes, P.J.; Fear, D.; Adcock, I.M.; Durham, A.L. BET proteins are a key component of immunoglobulin gene expression. Epigenomics 2017, 9, 393-406. [CrossRef]

141. Nicholls, S.J.; Schwartz, G.G.; Buhr, K.A.; Ginsberg, H.N.; Johansson, J.O.; Kalantar-Zadeh, K.; Kulikowski, E.; Toth, P.P.; Wong, N.; Sweeney, M.; et al. Apabetalone and hospitalization for heart failure in patients following an acute coronary syndrome: A prespecified analysis of the BETonMACE study. Cardiovasc. Diabetol. 2021, 20, 1-9. [CrossRef]

142. Ameratunga, M.; Braña, I.; Bono, P.; Postel-Vinay, S.; Plummer, R.; Aspegren, J.; Korjamo, T.; Snapir, A.; de Bono, J.S. First-inhuman Phase 1 open label study of the BET inhibitor ODM-207 in patients with selected solid tumours. Br. J. Cancer 2020, 123, 1730-1736. [CrossRef] [PubMed]

143. Li, G.; Zhang, Z.; Reszka-Blanco, N.; Li, F.; Chi, L.; Ma, J.; Jeffrey, J.; Cheng, L.; Su, L. Specific activation in vivo of HIV-1 by a bromodomain inhibitor from monocytic cells in humanized mice under antiretroviral therapy. J. Virol. 2019, 93, e00233-19. [CrossRef] [PubMed]

144. Lu, P.; Shen, Y.; Yang, H.; Wang, Y.; Jiang, Z.; Yang, X.; Zhong, Y.; Pan, H.; Xu, J.; Lu, H.; et al. BET inhibitors RVX-208 and PFI-1 reactivate HIV-1 from latency. Sci. Rep. 2017, 7, 1-12. [CrossRef] [PubMed]

145. Zhang, X.X.; Lin, J.; Liang, T.Z.; Duan, H.; Tan, X.H.; Xi, B.M.; Li, L.; Liu, S.W. The BET bromodomain inhibitor apabetalone induces apoptosis of latent HIV-1 reservoir cells following viral reactivation. Acta Pharmacol. Sin. 2019, 40, 98-110. [CrossRef] [PubMed]

146. Picaud, S.; Wells, C.; Felletar, I.; Brotherton, D.; Martin, S.; Savitsky, P.; Diez-Dacal, B.; Philpott, M.; Bountra, C.; Lingard, H.; et al. RVX-208, an inhibitor of BET transcriptional regulators with selectivity for the second bromodomain. Proc. Natl. Acad. Sci. USA 2013, 110, 19754-19759. [CrossRef] 
147. Liang, T.; Zhang, X.; Lai, F.; Lin, J.; Zhou, C.; Xu, X.; Tan, X.; Liu, S.; Li, L. A novel bromodomain inhibitor, CPI-203, serves as an HIV-1 latency-reversing agent by activating positive transcription elongation factor b. Biochem. Pharmacol. 2019, 164, $237-251$. [CrossRef] [PubMed]

148. Gallagher, S.J.; Mijatov, B.; Gunatilake, D.; Gowrishankar, K.; Tiffen, J.; James, W.; Jin, L.; Pupo, G.; Cullinane, C.; McArthur, G.A.; et al. Control of NF-kB activity in human melanoma by bromodomain and extra-terminal protein inhibitor I-BET 151. Pigment Cell Melanoma Res. 2014, 27, 1126-1137. [CrossRef]

149. Barrett, E.; Brothers, S.; Wahlestedt, C.; Beurel, E. I-BET151 selectively regulates IL-6 production. Biochim. Biophys. Acta Mol. Basis Dis. 2014, 1842, 1549-1555. [CrossRef]

150. Abner, E.; Stoszko, M.; Zeng, L.; Chen, H.C.; Izquierdo-Bouldstridge, A.; Konuma, T.; Zorita, E.; Fanunza, E.; Zhang, Q.; Mahmoudi, T; et al. A new quinoline BRD4 inhibitor targets a distinct latent HIV-1 reservoir for reactivation from other "shock" drugs. J. Virol. 2018, 92, e02056-17. [CrossRef]

151. Zhao, M.; De Crignis, E.; Rokx, C.; Verbon, A.; van Gelder, T.; Mahmoudi, T.; Katsikis, P.D.; Mueller, Y.M. T cell toxicity of HIV latency reversing agents. Pharmacol. Res. 2019, 139, 524-534. [CrossRef]

152. Huang, H.; Liu, S.; Jean, M.; Simpson, S.; Huang, H.; Merkley, M.; Hayashi, T.; Kong, W.; Rodríguez-Sánchez, I.; Zhang, X.; et al. A novel bromodomain inhibitor reverses HIV-1 latency through specific binding with BRD4 to promote Tat and P-TEFb association. Front. Microbiol. 2017, 8, 1035. [CrossRef]

153. Sánchez-Ventura, J.; Amo-Aparicio, J.; Navarro, X.; Penas, C. BET protein inhibition regulates cytokine production and promotes neuroprotection after spinal cord injury. J. Neuroinflammation 2019, 16, 1-12. [CrossRef] [PubMed]

154. Domínguez-Andrés, J.; Ferreira, A.V.; Jansen, T.; Smithers, N.; Prinjha, R.K.; Furze, R.C.; Netea, M.G. Bromodomain inhibitor I-BET151 suppresses immune responses during fungal-immune interaction. Eur. J. Immunol. 2019, 49, 2044-2050. [CrossRef] [PubMed]

155. Rueda, C.M.; Velilla, P.A.; Chougnet, C.A.; Montoya, C.J.; Rugeles, M.T. HIV-induced T-cell activation/exhaustion in rectal mucosa is controlled only partially by antiretroviral treatment. PLoS ONE 2012, 7, e30307. [CrossRef] [PubMed]

156. El-Far, M.; Halwani, R.; Said, E.; Trautmann, L.; Doroudchi, M.; Janbazian, L.; Fonseca, S.; van Grevenynghe, J.; Yassine-Diab, B.; Sékaly, R.P.; et al. T-cell exhaustion in HIV infection. Curr. HIV/AIDS Rep. 2008, 5, 13-19. [CrossRef]

157. Cheung, K.; Lu, G.; Sharma, R.; Vincek, A.; Zhang, R.; Plotnikov, A.N.; Zhang, F.; Zhang, Q.; Ju, Y.; Hu, Y.; et al. BET N-terminal bromodomain inhibition selectively blocks Th17 cell differentiation and ameliorates colitis in mice. Proc. Natl. Acad. Sci. USA 2017, 114, 2952-2957. [CrossRef] [PubMed]

158. Tanaka, M.; Roberts, J.M.; Seo, H.S.; Souza, A.; Paulk, J.; Scott, T.G.; DeAngelo, S.L.; Dhe-Paganon, S.; Bradner, J.E. Design and characterization of bivalent BET inhibitors. Nat. Chem. Biol. 2016, 12, 1089. [CrossRef]

159. Wang, Q.; Li, Y.; Xu, J.; Wang, Y.; Shi, D.; Liu, L.; Leung, E.L.H.; Yao, X. Computational study on the selective inhibition mechanism of MS402 to the first and second bromodomains of BRD4. Proteins 2019, 87, 3-11. [CrossRef] 